NBER WORKING PAPER SERIES

TRADE AND THE GREENHOUSE GAS EMISSIONS FROM INTERNATIONAL FREIGHT TRANSPORT

\author{
Anca D. Cristea \\ David Hummels \\ Laura Puzzello \\ Misak G. Avetisyan \\ Working Paper 17117 \\ http://www.nber.org/papers/w17117
}

\author{
NATIONAL BUREAU OF ECONOMIC RESEARCH \\ 1050 Massachusetts Avenue \\ Cambridge, MA 02138 \\ June 2011
}

We thank the OECD for funding, Ron Steenblik for suggesting and encouraging the work. We also thank Bruce Blonigen, Tim Cason, Lata Gangadharan, Tom Hertel, Pete Minor, Paul Raschky, Christis Tombazos, Terrie Walmsley, and seminar participants at the ASSA meetings 2011, and the International Workshop on Current Issues in CGE Analysis for suggestions and help. The views expressed herein are those of the authors and do not necessarily reflect the views of the National Bureau of Economic Research.

NBER working papers are circulated for discussion and comment purposes. They have not been peerreviewed or been subject to the review by the NBER Board of Directors that accompanies official NBER publications.

(C) 2011 by Anca D. Cristea, David Hummels, Laura Puzzello, and Misak G. Avetisyan. All rights reserved. Short sections of text, not to exceed two paragraphs, may be quoted without explicit permission provided that full credit, including $(\odot$ notice, is given to the source. 
Trade and the Greenhouse Gas Emissions from International Freight Transport

Anca D. Cristea, David Hummels, Laura Puzzello, and Misak G. Avetisyan

NBER Working Paper No. 17117

June 2011

JEL No. F17,F18,Q56

\begin{abstract}
$\underline{\text { ABSTRACT }}$
We collect extensive data on worldwide trade by transportation mode and use this to provide detailed comparisons of the greenhouse gas emissions associated with output versus international transportation of traded goods. International transport is responsible for 33 percent of world-wide trade-related emissions, and over 75 percent of emissions for major manufacturing categories like machinery, electronics and transport equipment. US exports intensively make use of air cargo; as a result two-thirds of its export-related emissions are due to international transport, and US exports by themselves generate a third of transport emissions worldwide. Inclusion of transport dramatically changes the ranking of countries by emission intensity. US production emissions per dollar of exports are 16 percent below the world average, but once we include transport US emissions per dollar exported are 59 percent above the world average. We use our data to systematically investigate whether trade inclusive of transport can lower emissions. In one-quarter of cases, the difference in output emissions is more than enough to compensate for the emissions cost of transport. Finally, we examine how likely patterns of trade growth will affect modal use and emissions. Full liberalization of tariffs and GDP growth concentrated in China and India lead to transport emissions growing much faster than the value of trade, due to trade shifting toward distant trading partners. Emissions growth from growing GDP dwarfs any growth from tariff liberalization.
\end{abstract}

Anca D. Cristea

University of Oregon

cristea@uoregon.edu

David Hummels

Krannert School of Management

403 West State Street

Purdue University

West Lafayette, IN 47907-1310

and NBER

hummelsd@purdue.edu
Laura Puzzello

Monash University

laura.puzzello@monash.edu

Misak G. Avetisyan

3XIEXH8 QYHHUW

425 W State Str, KCTR 237

West Lafayette, IN 47907-2056

mavetisy@purdue.edu 


\title{
Trade and the Greenhouse Gas Emissions from International Freight Transport
}

\author{
Anca Cristea, University of Oregon \\ David Hummels, Purdue University and NBER \\ Laura Puzzello, Monash University \\ Misak Avetisyan, University of Southern California
}

May 2011

\begin{abstract}
We collect extensive data on worldwide trade by transportation mode and use this to provide detailed comparisons of the greenhouse gas emissions associated with output versus international transportation of traded goods. International transport is responsible for 33 percent of world-wide trade-related emissions, and over 75 percent of emissions for major manufacturing categories like machinery, electronics and transport equipment. US exports intensively make use of air cargo; as a result two-thirds of its export-related emissions are due to international transport, and US exports by themselves generate a third of transport emissions worldwide. Inclusion of transport dramatically changes the ranking of countries by emission intensity. US production emissions per dollar of exports are 16 percent below the world average, but once we include transport US emissions per dollar exported are 59 percent above the world average. We use our data to systematically investigate whether trade inclusive of transport can lower emissions. In onequarter of cases, the difference in output emissions is more than enough to compensate for the emissions cost of transport. Finally, we examine how likely patterns of trade growth will affect modal use and emissions. Full liberalization of tariffs and GDP growth concentrated in China and India lead to transport emissions growing much faster than the value of trade, due to trade shifting toward distant trading partners. Emissions growth from growing GDP dwarfs any growth from tariff liberalization.
\end{abstract}

JEL classification: Q56; F18. Keywords: Greenhouse gas emissions; international transport emissions; world trade growth; international trade by transport mode

Acknowledgements: We thank the OECD for funding, Ron Steenblik for suggesting and encouraging the work. We also thank Bruce Blonigen, Tim Cason, Lata Gangadharan, Tom Hertel, Pete Minor, Paul Raschky, Christis Tombazos, Terrie Walmsley, and seminar participants at the ASSA meetings 2011, and the International Workshop on Current Issues in CGE Analysis for suggestions and help.

E-mail addresses: cristea@uoregon.edu (A. Cristea); hummelsd@purdue.edu (D. Hummels); laura.puzzello@monash.edu (L.Puzzello); mavetisy@purdue.edu (M. Avetisyan).

\section{Introduction}

International trade generates greenhouse gas (GHG) emissions from two sources: the production of traded goods, and their transportation between trading partners. A large literature has focused on 
the emissions associated with production, examining questions related to how trade may reallocate production between countries with differing emission intensities, or undermine efforts to control emissions via "carbon leakage". ${ }^{1}$ However, the emissions associated with international transportation are largely overlooked, both in the text of existing agreements such as the Kyoto Protocol regulations, and in data collection efforts. ${ }^{2}$

Efforts to measure the contribution of international freight transport to GHG emissions have been limited in scope. The case study based life cycle analyses (LCA) literature typically focuses on a particular product and geographic market, and assesses the environmental impact of every input in the production and delivery of that product. For example, Sim et al. (2007) estimate that the global warming impact of Kenyan and Guatemalan beans shipped to the UK are 20-26 times larger than UK production. In contrast, Williams (2007) finds that cut roses air delivered from Kenya to the UK generate emissions that are significantly lower than roses sourced from the neighboring Netherlands (Williams, 2007). While LCA studies provide detailed calculations of transport emissions for a particular product and trade flow, they are not informative for the world trading system as a whole. ${ }^{3}$ More generally, we lack data sources that attribute international transport emissions to origin and destination countries. As a consequence, there is little systematic information regarding the magnitude of transportation emissions relative to production, and how they are distributed across trade flows.

\footnotetext{
${ }^{1}$ Examples include Ederington and Minier (2003), Babiker (2005), Levinson (2009), Levinson and Taylor (2008) among others. See also Copeland and Taylor (2004) for a comprehensive literature survey.

${ }^{2}$ van Veen-Groot and Nijkamp (1999) argue that the key research focus in advancing the investigation on the environmental effects of international trade should be on "building up a monitoring system and database" to facilitate "measuring the environmental effects of international transport". For a discussion of the challenges in measurement and the omission of international transport from policy protocols see Olivier and Peters (1999), Miljøstyrelsen Miljøministeriet (2003) - the Danish Environmental Protection Agency, Danish Ministry for the Environment, as well as the Transportation Research Board, 2009.

${ }^{3} \mathrm{~A}$ few recent papers employ input-output tables to measure international trade emissions, and attempt to incorporate international transport emissions into the calculation (Grether et al., 2010; Peters and Hertwich, 2008; Cadarso et al., 2010). However, data on the modes of transport by which goods travel is not readily available at a global scale, so these papers either restrict their attention to a single importing country or they base their calculations on entirely imputed data.
} 
How important are international transport emissions relative to emissions from the output of traded goods? The International Transport Forum (ITF 2010) provides aggregate transport emissions data for international aviation and maritime transport by combining data on fuel consumption from the International Energy Agency (IEA 2010), along with information on GHG emissions by fuel type. Table 1 provides the ITF estimates along with additional calculations by the authors. From 1990-2004, international transport emissions rose slightly faster than total emissions or emissions from all transport. Focusing on 2004, international maritime plus international aviation transportation was responsible for just 3.5 percent of total emissions. This seems small, but total emissions include many activities (e.g., residential energy usage, domestic transportation), which are not directly related to trade or the output of tradable goods. The IEA estimates that industrial production represents only a fifth of worldwide emissions, and most industrial output emissions are unrelated to trade - e.g., if a quarter of steel output is traded then three quarters of the output emissions from steel correspond to domestic consumption. This suggests that international transport measured as a share of trade-related emissions (which we define as emissions generated by the production and transport of exported goods) could be substantial, but careful measurement is needed.

By measuring actual fuel use the ITF "top-down" approach is an accurate way to assess worldwide aviation and maritime emissions in a particular year. However, the ITF approach has two key drawbacks. First, road and rail transport represent a significant fraction of international trade for land-adjacent partners but their emissions are omitted from the ITF numbers because international and domestic fuel usage is indistinguishable. This is especially problematic because road and rail transport is a rising share of world trade as regional trade liberalization, especially in North America and Europe, concentrated trade growth between partner countries sharing land borders. Road and rail growth is omitted from ITF emission numbers, which raises the question of whether the sharp decline in emissions per dollar of trade shown in Table 1 is real or spurious. 
The second drawback is that one cannot use the aggregate ITF numbers to assess where or how maritime or aviation fuel was used. Even if one were to track fuel loaded to individual ports this would be of limited use as ships and planes refueling in a particular port could be carrying cargo of any type between any country pair in the world. Without knowing where fuel is used we cannot evaluate the total emissions associated with a particular trade flow (i.e., a specific product traded between a country pair). Nor can we estimate whether emissions will rise faster or slower than overall trade growth, or understand which trade flows would be most affected by efforts to mitigate emissions.

Complicating matters further, the contribution of transport to trade-related emissions can differ dramatically across trade flows. Standard analyses in the trade literature focus on trade value, while ignoring the weight of trade and how goods move. But emissions depend on the mode employed and weight, not value, transported. One million dollars of coal is vastly heavier than a million dollars of microchips, with correspondingly larger transport emissions. Trucks, rail, airplanes and ships have significantly different GHG emissions and modal use varies widely across trade flows. One kilogram of cargo flown one kilometer on a plane generates between 50 and 200 times the emissions of that same kg-km on a bulk cargo carrier. The product and partner composition of trade has a first-order impact on the types of transportation employed, and on the associated GHG emissions. As a consequence, we learn little from the aggregate incidence of transport emissions that can be directly applied to particular trade flows.

The purpose of this paper is to provide two exercises, both of which are novel in the literature. In the first we build an extensive database on output and transport emissions associated with every origin-destination-product trade flow worldwide in a base year 2004. We employ this database to quantify the contribution of international transport to total emissions, and to highlight systematic patterns of transport emission intensities across products and trade pairs. In the second exercise, we calculate the emissions growth due to a simulated change in global trade arising from 
tariff liberalization and unevenly distributed GDP growth. In analyzing the simulated changes in overall GHG emissions, we distinguish between scale (i.e., changes in the derived demand for international transport services) and composition effects (i.e., changes in the relative use of transport modes of varying emission intensities). ${ }^{4}$

We begin by combining trade and emissions data by mode in order to provide a full accounting of the emissions associated with international transportation for each individual trade flow. This "bottom-up" accounting of emissions yields aggregate worldwide emissions that are remarkably close to matching the "top-down" accounting provided by the ITF 2010. Unlike the ITF aggregate data, these emissions numbers are specific to each origin-product-industrial sector. This allows us to calculate the emissions associated with a dollar of trade and decompose it into a production and a transport component.

We next describe the importance of transport relative to production emissions for specific trade flows, and show which trade flows are especially emissions intensive once both components are taken into account. World-wide, 33 percent of trade-related emissions come from international transport, though this number is considerably higher in the manufacturing sectors: 80 percent of trade-related emissions in machinery exports come from international transportation. There is also wide variation across countries in the contribution of transport to trade-related emissions. At the low end, only 14 percent of Indian and Chinese export emissions come from transport, while transport is responsible for 66 percent of US export emissions due to substantial use of air cargo. The magnitude of transport's contribution to total emissions suggests that policies designed to mitigate carbon output must take international transport into account and further, that the design of such policies could have pronounced distributional effects. For example, the US is responsible for one third of transport emissions but only 12 percent of output emissions. And while US imports

\footnotetext{
${ }^{4}$ In our simulation exercises, the technique effect (i.e., changes in the emission intensity of transport services) is held constant at the base year level. Notice that while several studies have decomposed the overall change in production emissions into scale, composition and technique effects (see for example Levinson, 2009; Grether et al., 2010), our focus in this paper is on trade-related emissions.
} 
and exports are very similar in terms of the emission intensities of production, once we include transport, its exports have double the emission intensity. Whether transport emissions are allocated to the exporter or the importer thus becomes a significant issue for welfare analysis. Rising trade induces emission changes by boosting transport emissions, and by reallocating production toward countries with different production emission intensities. By characterizing both production and transport emissions from trade flows we can address systematically the questions answered previously using case studies, namely, does consuming foreign goods raise or lower GHG emissions once international transport is accounted for? We examine a set of "partial equilibrium" reallocations in which a country lowers its own production and instead buys the good from abroad. Just over a quarter of changes in specialization would lead to a reduction in emissions, with much higher numbers in resource-based industries and in the developing world. ${ }^{5}$

These partial equilibrium reallocations are meant to be illustrative. They do not contemplate whether the reallocation is feasible, what kinds of shocks would induce it, or what possible general equilibrium effects might exacerbate or attenuate the change. To consider these issues we next simulate the level and composition of trade growth in four scenarios related to trade liberalization and a fifth scenario examining differential changes in country GDP growth rates through the year 2020. Trade liberalization and output growth are likely to lead not only to growth in the quantity of trade but also to changes in its product and country-pair composition. The question is then whether growth will occur in high or low emissions categories, and whether transport emissions are likely to grow more rapidly than output emissions. Combining simulated output and trade changes with our emissions data we can then calculate the predicted growth in emissions from trade.

Our findings are as follows. Trade liberalization scenarios currently contemplated under the Doha WTO round generate very small changes in output, exports, and GHG emissions. Full liberalization

${ }^{5}$ These emission-reducing trade pairs are non-trivial, corresponding to 31 percent of global trade by value. 
results in a 6 percent increase in trade, concentrated in those products that are subject to the highest rates of protection. More importantly, liberalization eliminates tariff preferences enjoyed primarily by nearby trading partners (e.g., NAFTA and the EU). Trade shifts away from proximate partners and toward distant partners who cannot be reached by land transport. Use of air cargo rises, and with it, GHG emission rise 23-42 percent faster than trade.

In contrast to the modest effects from tariff liberalization, projected output growth (a 75 percent increase in gross world product by 2020) leads to profound changes in trade and emissions. Exports rise at 3.8 percent per year, 80 percent cumulatively, while transport services (kg-km) rise 173 percent cumulatively as trade shifts to distant but rapidly growing China and India. Transport emissions grow faster than trade by value and faster than output emissions, with especially rapid growth in maritime emissions.

The paper proceeds as follows. Section Two describes the methodology and Section Three describes the construction of the main data components for our exercises. Section Four provides evidence on current contribution of international transportation to GHG emissions from international trade. Section Five provides simulations of trade growth, and calculates how this growth would affect modal use and emissions. Section Six concludes.

\section{Methodology: Base Year Emissions}

The International Transport Forum (ITF 2010) uses data on fuel consumption to calculate emissions associated with international transport. As discussed in the introduction, this "topdown" approach provides accurate measures of worldwide emissions, but has a number of significant drawbacks because it cannot assign emissions to particular trade flows. We use a "bottom-up" approach in which we construct the emissions associated with a trade flow by calculating the quantity of transportation services for that flow provided by each transportation mode, and multiplying by emissions per unit of transportation services. 
Denote $E_{\text {odg }}^{T}$ as the GHG emissions ${ }^{6}$ associated with transporting good $g$ from origin $o$ to destination $d . V A L$ is the value of that flow, and $W V$ is the weight to value ratio so that $V A L_{\text {odg }} * W V_{\text {og }}$ is the quantity of the flow in kilograms. A country pair may ship product g using multiple transportation modes. The quantity share of mode $m$ in that flow is $Q S_{\text {odg }}^{m}$, so $V A L_{\text {odg }} * W V_{o g} * Q S_{o d g}^{m}$ gives the quantity of the flow for each mode, in kg. Multiplying by $D I S T_{\text {od }}^{m}$ the distance traveled from $o$ to $d$ for mode $m$ gives us a measure of transportation services, for each mode, measured in a common unit (one kg of cargo moved one kilometer). Finally, multiplying by $e^{m}$, the GHG emissions produced by mode $m$ when providing one kg-km of transportation services, and summing over all modes yields the total emissions associated with that trade flow.

$$
E_{\text {odg }}^{T}=\sum_{m} V A L_{o d g} * W V_{o g} * Q S_{o d g}^{m} * D I S T_{o d}^{m} * e^{m}
$$

This bottom up approach has a few limitations owing to data availability. This formulation imposes a constraint that emissions for a given mode are common to all products and country pairs and are linear in weight and distance. As such it masks two potentially important sources of heterogeneity. One, some trade flows may employ older, smaller ships and planes with higher emissions per kg-km of transportation services. We partially adjust for this problem in the data by allowing for multiple types of ocean vessels that are specific to certain cargos, and by experimenting with aviation emissions data that reflect the most efficient planes versus those in use in existing fleets. Two, there are emissions associated with "fixed costs" of transport, incurred independent of distance traveled, including port time for ships and higher landing/take off emissions for planes. We provide calculations to suggest that these problems, while significant at very short distances, become insignificant at the international distances seen in the data.

An additional limitation relates to emissions from domestic transport linked to trade. All production requires domestic transport, and we capture this input and its associated emissions as

${ }^{6 " G H G}$ emissions" refer to both $\mathrm{CO} 2$ and non-CO2 emissions, represented as $\mathrm{CO} 2$ equivalents. 
part of output emissions. If production for external trade uses domestic transport to the same extent as production for domestic use, then we capture domestic transport emissions accurately. However, in some instances external trade may require movement of goods over great internal distances, while in others (production near borders, or near air or seaports) external trade may employ very little domestic transport. This may result in under- or over-counting trade-related emissions, but we have no clear indication if there is a bias or which way it runs. Note that this is fundamentally similar to any case in which a heterogeneous production technology is characterized by an aggregate technology.

Starting from equation (1), we can provide a number of comparisons and calculations. Trade flows are most commonly reported in value terms. Pulling the value of the trade flow out of this summation we can decompose the quantity of transportation emissions from the flow into a scale measure and an intensity measure

$$
E_{\text {odg }}^{T}=V A L_{\text {odg }} * e_{\text {odg }}^{T} \quad \text { where } \quad e_{\text {odg }}^{T}=\sum_{m} W V_{o g} * Q S_{o d g}^{m} * D I S T_{o d}^{m} * e^{m}
$$

Using this basic decomposition we can compare the transport emissions from exports across countries. Summing over importers and products, an exporter $o$ 's emissions are

$$
E_{o}^{T}=V A L_{o} * e_{o}^{T}=V A L_{o} * \sum_{d g} S_{o d g} * e_{o d g}^{T}
$$

where $s_{\text {odg }}$ is the share of destination $d, \operatorname{good} g$ in total trade for origin $o$. Transport emissions depend on the scale of trade and the transport emission intensity of a dollar of trade. The latter is a trade-weighted average of emissions from individual flows. If an exporter engages in trade with more distant partners, trades heavier goods, or uses aviation more than maritime transport it will have a higher aggregate transport emission intensity. We can provide similar aggregations by importers (aggregating over exporters and products) or by products (aggregating over country pairs). 
We can also use this decomposition to compare the emission intensity of trade arising from two distinct sources: production of traded goods and transport of traded goods. Begin by writing the emissions from output of good (or service) $g$ in country $o$ as the product of output (in dollars) and emissions per dollar of output,

$$
E_{o g}^{Y}=Y_{o g} * e_{o g}^{Y}
$$

so that aggregate emissions in a country are an output weighted average of emissions for each activity.

$$
E_{o}^{Y}=Y_{o} * \sum_{g} s_{g} * e_{o g}^{Y}
$$

Aggregating again over all countries yields worldwide emissions, similar to that found in Table 1. If we instead measure both output and transport emissions as an intensity (i.e., CO2 equivalents per dollar), we can calculate the contribution of each emission component to the total emission associated with a particular trade flow. For any particular $o-d-g$ flow we have:

$$
E_{\text {odg }}=\left(e_{\text {odg }}^{T}+e_{o g}^{Y}\right) * V A L_{o d g}
$$

This representation is also convenient as it allows for an immediate calculation of the tariff equivalent of policies designed to reduce total trade-related emissions. Suppose a trade flow produces 200 grams of $\mathrm{CO} 2$ equivalent emissions per dollar of trade, and faces a carbon tax of $\$ 50$ per ton. The carbon tax raises the cost of that trade flow by one percent, and so is equivalent to a $1 \%$ tariff.

Much of our analysis will consist of a few basic but informative calculations. We will compare the magnitudes of $e_{o d g}^{T}, e_{o g}^{Y}$ for particular trade flows, and in the aggregate for different regions. We will also analyze whether moving output from a high emission to a low emission producer induces emission changes that are large or small relative to reallocating trade across partners from high transport emission trade flow to a low transport emission trade flow. 


\section{Data}

In this section we describe the main data components necessary to describe GHG emissions from output and international transportation in the base year. These data components are: the weight, value, and modal shares of trade for each bilateral pair and product; the GHG emission intensity for each transportation mode; and GHG emissions associated with output for each producer x sector. Given the improvement in quality and coverage that these new sources of data provide, and their likely use in future research on transport and trade-related emissions, we devote much attention to document the construction of the dataset.

\section{A. Aggregation}

These disparate data components must fit together precisely, using the same level of regional and product aggregation. In this we are most constrained by the data available for output emissions, which we take from the database underlying version 7 of the Global Trade Analysis Project (GTAP) model. The GTAP database is ideal for our purposes because it contains detailed information on energy usage and GHG emissions by origin country and sector, and because we can use the GTAP computable general equilibrium model in the final section of the paper for performing trade liberalization and output growth simulations.

At its maximum disaggregation, GTAP 7 allows one to model production and trade for 57 traded and non-traded sectors between 113 countries. While it is not computationally feasible to run trade experiments with the full 113 country x 57 sector version of the model, GTAP allows for flexible aggregation across regions and sectors in order to examine certain especially interesting subsets of the whole dataset. For current purposes, we employ an aggregation of the model with 40 regions (i.e. ,1600 bilateral pairs), and 23 traded goods and 6 non-traded goods sectors, the detailed listing of which is reported in Appendix 1.

This particular aggregation scheme was chosen to serve two purposes. One, countries and sectors with "similar" transportation characteristics are aggregated together. For example, all sub- 
categories of bulk agriculture, which primarily uses maritime transport, are aggregated into one category while sub-categories of processed agriculture, which is more likely to employ air transport, are aggregated into a second category. Two, we employ country level aggregation in cases where we have detailed weight/value and transportation mode data, and broader geographic aggregation for regions where these data are lacking. For example, we represent the Middle East and Africa in only 3 aggregated regions, while Europe is represented with 15 individual countries and 3 aggregated regions. This allows us to minimize the amount of imputation that must be employed to complete the database.

\section{B. Trade and Output in the Base Year: Weight/Value, and Modal Shares}

Recalling equation (1), we need data on the value of trade, the weight/value ratio, and the quantity shares of each mode.

Our base dataset for the value of output and trade comes from the GTAP 7 database, aggregated to 40 regions and 29 sectors (23 traded) in 2004. By multiplying values in dollars by a weight/value ratio (kg/dollar) that is specific to each origin $\mathrm{x}$ sector, we convert these value of trade numbers into kilograms. This physical unit of measurement is consistent across countries and products, is meaningful from a transportation perspective, and can be used directly to calculate GHG emissions from transport.

To construct $W V_{\text {og }}$ we draw on three primary data sources that report trade by value and weight at the 6 digit level of the Harmonized system (roughly 5000 products). These are: US Imports and Exports of Merchandise; Eurostats Trade (covering the imports and exports of $27 \mathrm{EU}$ countries) ${ }^{7}$, and the ALADI trade database, covering the imports of 11 Latin American countries (Argentina, Bolivia, Brazil, Chile, Colombia, Ecuador, Mexico, Paraguay, Peru, Uruguay and

\footnotetext{
7 Data on trade outside the EU by transport mode are available at the HS6 level. Data on exports from EU15 to EU25 countries (excluding Bulgaria and Romania) by transport mode are reported at the 3 digit level of the NSTR and were compiled on special request by statisticians at Eurostats.
} 
Venezuela) from all exporters worldwide. The bilateral pair coverage represented by these three datasets is displayed in Appendix 2.

It is necessary to concord the HS6 data to the 23 merchandise trade sectors used in our aggregation of the GTAP model. This means that for each importer and exporter there may be several hundred HS codes corresponding to a single GTAP sector such as "electronic equipment". To arrive at a weight/value ratio for each exporter and product, we separately sum the weight of trade and the value of trade and express them as a ratio. This is equivalent to a share-weighted average of the weight/value ratio for each HS6 product traded by that exporter. ${ }^{8}$

For reference we report data by commodity in Appendix Table A1. This includes initial tariff rates and weight/value ratios (each expressed as a trade-weighted average over all country pairs), along with the share of each commodity in world output, world trade by value, and world trade by transportation services units (kg-km). Of interest, some of the goods that represent a larger value share in trade (electronic equipment and machinery) represent a significantly smaller share in transportation services. This reflects large differences in weight/value between these manufactured goods and heavy products such as bulk agriculture, minerals, and oil.

The data for modal shares, $Q S_{o d g}^{m}$, come from the same three sources as the weight/value data described above. Each of those datasets contains information on the weight and value of trade by origin-destination-product and transport mode. The US data split trade into air and ocean modes, but has no modal information on overland transport from Mexico and Canada. To disaggregate these flows into truck and rail we use supplementary data from the Transborder

\footnotetext{
${ }^{8}$ We do not employ weight/value ratios that vary across importers because we do not have weight data for every $o-d-g$ triplet in the data. Apart from the $o$ - $d$ pairs with no data, the weight field is missing from roughly 20 percent of EU observations, though these tends to be relatively small value flows and unrelated to modal use. In general, because aggregating over importers for a given exporter and product reduces measurement error in the more noisy weight data.
} 
Surface Freight Data. ${ }^{9}$ The EU and ALADI datasets report trade by air, ocean, rail, and truck modes. Modal use for the US, ALADI, and EU trade with non-EU partners are measured at the HS6 level. Intra-EU trade is measured at the NSTR 3 digit level. To construct modal quantity shares, we first concord the HS6 (or NSTR3) product codes to GTAP sector groupings, and aggregate so that we have the weight of trade for each mode within each $o-d-g$ triplet.

For 35 percent of world trade by value we have no direct data on modal use. In these cases we estimate modal shares as a function of geography, country, and product characteristics basing our estimation sample on those country pairs that do report modal data. These regressions have good explanatory power, especially in the vast majority (all but 2 percent) of the remaining cases where land transport is not an option. Details are provided in Appendix 2.

The results of our data collection generate a full matrix of modal shares for each origin-destinationGTAP sector by value, weight, and transportation service units (kg-km). Table 2 provides modal shares for the imports and exports of each continent, by trade value and KG-KM. Appendix Table A2 reports the numbers by traded sectors.

A few things are notable. There are large differences across regions in the value shares of the transportation modes that largely reflect geography. For example, North America and Europe, with important land-adjacent trade partners, rely much more heavily on road transport.10 Substitution between air and ocean cargo is especially important as it reflects the largest gap in emission intensities. Worldwide 18 percent of trade by value is air-borne, with much higher ratios in North American and East Asian exports. Excluding land-based modes, air transport represents

\footnotetext{
${ }^{9}$ The TBSF data have rail v. road splits at the HS2 level. We take each land-based trade flow from the more disaggregated HS 6 data and divide it using the splits found in the corresponding HS 2 data. We then aggregate to the broader 23 sectors found in the GTAP data.

10 Most of Asia has very small shares of land transport because the largest trading partners are separated by (short) stretches of ocean. South America, for which land transport is actually an option has rather low land transport shares, probably because economic activity is concentrated on coasts rather than in the interiors close to land borders. When we disaggregate to the country level there are more dramatic differences. Europe as a whole has very high shares of rail and road transport, except for countries like the UK, Ireland, and Finland.
} 
48 percent of international (air + ocean) cargo for North American exports and 27 percent for European and Asian exports.

It is also instructive to contrast the value of trade with the transportation services (KG-KM) employed by trade. Here, sea transport dominates with 95 percent of transportation services provided. Products that are heavy, and that are transported long distances, are much more likely to be sea-borne. The largest difference relative to value shares comes in the use of road-based transport: while it represents nearly half of European imports by value it is only 5 percent of European imports by KG-KM. Road transport constitutes a large share of value and weight moved in European trade; however it is concentrated in the trade of proximate partners. As a result, road transport represents a very small share of kilogram-kilometers shipped.

\section{Greenhouse Gas Emissions by Transport Mode}

We draw on data from several studies to calculate emissions per kg-km of cargo moved by each of the four transport modes: ocean, air, rail, and road. These sources, and data on emissions, are reported in Table 3. We briefly remark on the data for maritime and aviation emissions here. The most recent and comprehensive study for maritime transport comes from "Ship Emissions Study", National Technical University of Athens Laboratory for Maritime Transport (2008). It reports emissions in grams of $\mathrm{CO} 2$ per tonne-km shipped for many distinct ship types, as well as variability across vessels of different sizes within each type. ${ }^{11}$ In Table 3, we reproduce the fleet averages for six ship types, and note the ship types employed for each traded goods sector in our model. While other studies lack the detailed data by ship type reported in that study, those studies (Kristensen 2006, Giannouli and Mellios, 2005) that provide data for containerized cargo arrive at similar emission numbers.

\footnotetext{
11 In general, $\mathrm{CO} 2$ emissions per tonne-km shipped are much lower for larger vessels within each type. For example, post-Panamax ( $>4400 \mathrm{TEU}$ ) containerships produce $1 / 3$ the emissions of a less than 500 TEU feeder ship. Because we have no data on the ship size composition of flows, we employ fleet averages for each fleet type. The study also provides data for highly specialized ship types such as Reefers and Ro-Ros. We do not employ this data as our broader trade aggregates contain a mix of goods that would employ these specialized types as a small subset of goods that generally employ container vessels.
} 
In searching the literature we found few estimates of emissions associated with air cargo. These arrive at widely varying estimates of emissions per tonne-km, and provide little detail on methodology. For example, a Maersk 2007 pamphlet cited in the University of Athens (2008) study reports that a Boeing 747-400 emits 552 grams of CO2 per tonne-km shipped. A California Climate Change pamphlet for 2006 reports emissions per tonne-km shipped ranging from 476-1020 grams of $\mathrm{CO} 2$.

Given this wide range, we attempted our own calculations based on fuel usage and fleet characteristics. The Air Transport Association of America reports fleet wide fuel usage and tonmiles of cargo shipped for US cargo airlines. Using these totals we calculate that US cargo airlines used 163.6 gallons of jet fuel per thousand ton-miles shipped. Converting gallons of jet fuel into grams of CO2 and cargos into tonne-km, we calculate CO2 emissions of 963.5 grams of CO2 per tonne-km.

We also attempted to construct an independent estimate of CO2 emissions associated with air cargo using data taken from Aircraft Economics, 1999, "Freighter Cost Comparisons". This source provides data for 14 major cargo plane types including total fuel use, revenue ton-miles flown, and share in the fleet. Combining fuel use, emissions per gallon of jet fuel, and ton-km flown it is possible to construct a measure of average $\mathrm{CO} 2$ emissions per tonne-km flown. The numbers range from 493 to 1834, depending on the plane type and how it was used (i.e. for short v. long haul cargo carriage). For comparison, applying this method to the Boeing 747 yields emissions of 700 grams of $\mathrm{CO} 2$ per tonne-km, which is close to the Maersk study. Taking a weighted average of these emission numbers over the fleet shares reported, we arrive at average emission rate of 972 grams. Finally, if we update the fleet composition using 2008 shares (from ATA) we arrive at average emissions of 912.1 grams.

In the calculations that follow we employ $552 \mathrm{~g} / \mathrm{t}-\mathrm{km}$ as a "LOW" emissions value for aviation. This corresponds to use of the most efficient aircraft on the longest flights. We use 950 
$\mathrm{g} / \mathrm{t}-\mathrm{km}$ as a "HIGH" emissions scenario, and it corresponds to a use of a mixed fleet of smaller planes on shorter flights.

To amplify this last point, landing/take off (LTO) requires high fuel use relative to cruising, but this effect is most pronounced at short distances. We collected detailed data from EEA Emission Inventory Guidebook 2007 on fuel usage on LTO and cruise for a variety of planes and calculated emissions per ton-km for various trip lengths to see how this would affect our calculations. For example, a 747-400 with a 60\% load factor on a $1852 \mathrm{~km}$ flight emits $556 \mathrm{~g} / \mathrm{t}-\mathrm{km}$ (close to our LOW scenario), while that same plane and load factor emits $912 \mathrm{~g} / \mathrm{t}-\mathrm{km}$ on a $463 \mathrm{~km}$ flight. This represents an important diseconomy of scale for much shorter flights of the kind one would see with domestic US cargo usage. However, once one gets to flights of international distances, the effects become muted. At $463 \mathrm{~km}$, LTO fuel represents nearly 55\% of total fuel use, dropping below $5 \%$ for distances above $6000 \mathrm{~km}$. The median travel distance in our data is $8000 \mathrm{~km}$.

The final component we need to calculate transport emissions is distance traveled. For rail, road, and air transport we rely on the simple distances reported by the CEPII. ${ }^{22}$ Bilateral distances between country pairs are calculated following the great circle formula, which uses latitudes and longitudes of the most important city in each country. ${ }^{13}$ For ocean transport direct line distances significantly understate actual distances traveled. Containerships rarely travel point to point between importer and exporter and frequently stop at multiple ports of call en route. We draw on a dataset of actual ship itineraries from Hummels and Schaur (2011) that allow us to calculate actual distances traveled due to these indirect routings.

\section{Greenhouse Gas Emissions from Output}

The GTAP 7 database provides data on GHG emissions produced by each sector $g$ in each country $o$, $E_{\text {og }}^{Y}$ in equation (4). We briefly summarize how these data were constructed, and direct readers to

\footnotetext{
12 The CEPII dataset is available for download at http://www.cepii.fr/anglaisgraph/bdd/distances.htm. ${ }^{13}$ For aggregation at the regional level we weighted each constituent country's distance by its GDP share in the region's GDP.
} 
more detailed discussions available from Lee (2008) and Rose et al (2010). For each o-g pair, the database contains information on use of six energy inputs (coal, oil, gas, petroleum products, electricity, and gas distribution). Energy use differs across countries and sectors as a function of the energy intensity of production, the efficiency with which energy is used, and the availability of energy inputs in the respective country. Using a standard formulation provided by IPCC (1997) guidelines, the quantity of energy inputs is then converted into $\mathrm{CO} 2$ emissions. Finally, these data are supplemented by calculating non-CO2 greenhouse gases emitted as a by-product of production (primarily in agriculture). These are converted into $\mathrm{CO} 2$ equivalents based on their global warming potentials, following the methodology in USEPA (2006).

Combining these data we have total GHG emissions for each country $o$ and sector $g$. To provide comparisons to our transportation emissions, we describe these as emission intensities per dollar of output $e_{o g}^{Y}$ by dividing total emissions for $o-g$ by the market value of output.

\section{Transport and Output Emissions in the Base Year}

In this section we provide three main exercises. First, we compare our "bottom-up" approach to calculating international transport emissions to the ITF "top-down" approach as a methodological check. Second, we compare transport to output emissions for a given trade flow to gauge the importance of transport emissions in trade. Third, we use the transport and output data in combination to consider whether some partial equilibrium changes in the pattern of specialization and trade will yield rising or falling GHG emissions.

\section{A. Aggregate Emissions from International Transport: Comparing Methodologies}

Our "bottom-up" approach to emissions calculates the quantity of transportation services (KG-KM) performed by each mode in each origin-destination-product trade flow, and then multiplies by emissions per KG-KM for each mode. This yields transportation emissions that are specific to nearly 36,000 individual trade flows. Summing over all trade flows we have an alternative estimate 
of total CO2 emissions from international transport. How does this bottom up approach compare to the top down ITF (2010) approach based on worldwide fuel usage? The answer is: surprisingly well. In 2004, the ITF calculates that international aviation and maritime transport was responsible for 910 million tons of $\mathrm{CO} 2$ production, 520 from maritime and 390 from aviation. We calculate 522 million tons of maritime emissions. When we employ the LOW emissions intensity we calculate aviation emissions of 419 (and a total of 941 million tons) in 2004. ${ }^{14}$ Accordingly, we will focus most of our subsequent calculations on the LOW aviation emissions scenario. While there are large methodological differences between our approach and the ITF, we match emission aggregates quite closely. This gives us confidence that our estimates for disaggregated flows will also be informative.

Using our more comprehensive emissions data we calculate that total international transport emissions are 1205 million tons in 2004. Measured relative to the value of world trade, international transport emits 146 grams per dollar of trade, while output of traded goods generates 300 grams per dollar of trade. That is, total trade-related emissions are 446 grams per dollar, of which 33 percent come from international transport. For perspective, a $\$ 50$ per ton carbon tax applied to the average international transport emissions would be equivalent to a 0.73 percent tariff.

Our calculation of 1200 million tons of CO2 equivalent contrasts with the 910 million tons calculated by the ITF. By omitting road and rail, the ITF calculation misses 28 percent of international transport emissions. This may help to explain a curious pattern in Table 1 . Using the ITF emission numbers we see that international (maritime plus aviation) transport emissions per dollar of world trade dropped sharply from $159 \mathrm{~g} / \$$ in 1990 to $93 \mathrm{~g} / \$$ in 2004 . Why did trade

\footnotetext{
${ }^{14}$ Note that the HIGH aviation intensity, based on the current composition of the US air cargo fleet, yields aviation emissions of 721 million tons, much higher than the ITF values. There are two possible explanations here. One, the ITF separates fuel use into domestic and international usage. If some international fuel use were inaccurately recorded as domestic usage, they would under-estimate emissions. Two, it may be that the composition of the US air cargo fleet, including smaller planes and shorter routes than are typically found in international aviation, may overstate emissions.
} 
appear to become less emission intensive from 1990-2004? The key is that land-based trade, omitted from the ITF emission values, interacts in an interesting way with the structure of protection. In this period trade grew especially fast with land-adjacent partners, ${ }^{15}$ promoted by policy measures that offer preferential tariff rates, investment rules, regulatory harmonization and currency union with those close partners. Table 2 shows that international road and rail are responsible for nearly a third of world-trade by value - half of intra-European trade by value is land based.

Note, however, that this pattern need not persist. Were trade liberalization at the multilateral level to erode preferential tariff rates, or were output to grow more rapidly outside of North America and Europe, trade would likely shift towards distant partners. We revisit this point in Section Five.

\section{B. Emissions from Trade: Comparing Output and International Transportation}

We begin by comparing trade-related emissions from output of traded goods and international transport at the level of 35,880 individual trade flows (that is, 40 exporters x 39 importers x 23 traded goods sectors). We plot the distribution of emission intensities as CO2 grams per dollar of trade in Figure 1. Output and transport emissions are similarly distributed because they have similar medians (transport - $120 \mathrm{~g} / \$$, output - $137 \mathrm{~g} / \$$ ) and are highly correlated at the level of individual trade flows. ${ }^{16}$

There is a wide variance in both transport and output emissions, ranging from close to zero grams of carbon per dollar to well over $2 \mathrm{~kg}$ of $\mathrm{CO} 2$. This variance is notable because the average

\footnotetext{
15 This pattern, in sharp contrast to the conventional wisdom pointing to the "death of distance" has been pointed out by several authors looking at the effect of distance variables in gravity regressions (Disidier and Head, 2008; Berthelon and Freund 2008), and others who have noted the remarkably large effect of NAFTA and EU liberalization policies on trade within those regions.

16 Trade flows with high output emissions also have high transport emissions, and this is true whether we look at total emissions or emissions intensities. A regression of transport emission intensities on output emission intensities for the exporter yields an elasticity of 0.26 and an $\mathrm{R} 2=0.10$. A regression of total emissions from transport on total output emissions yields an elasticity of 0.76 and an R2=0.73.
} 
value of 145 grams/\$ for transport as a whole is driven by a concentration of trade in o-d-g flows with very low emission intensities. There are many flows with much higher emissions, and carbon taxation would have a pronounced effect on these goods. For comparison, the world-wide average tariff rate in our data is 3.2 percent, which is equivalent to a carbon tax of $\$ 50$ applied to a trade flow with transport emissions of 650 grams $/ \$$.

Next we examine the contribution of transport emissions to trade-related emissions when calculated on a common per dollar basis. We aggregate transport emissions for each industry by summing over all country pairs. Taking the transport emissions for each industry and dividing by the value of trade yields a (weighted average) transport emission intensity for that industry. A similar procedure yields the average output emissions intensity. Adding these together as in equation (5) enables us to calculate the share of transport emissions in total trade-related emissions for each industry. Figure 2 provides this comparison with industries sorted from smallest to largest transport emissions share (data in grey, scale displayed on the right vertical axis). For perspective we also display transport emissions for that industry as a share of total transport emissions (data in blue, scale displayed on the left vertical axis). Recall that worldwide transport is responsible for 33 percent of trade related emissions. At the industry level we see wide dispersion in these numbers. At the low end are bulk products (agriculture, mining) with significant output emissions, and which tend to be shipped using the most efficient maritime bulk carriers. At the high end are manufactured goods. Over 75 percent of the trade-related emissions of transport equipment, electronic equipment, machinery, and manufactures not elsewhere classified come from transportation.

In Table 4 we provide similar calculations for international transport and output emissions by regional groupings and for selected countries (for the full sample of countries see Appendix Table A3). The first three columns show the contribution of each region to trade-related emissions worldwide, including emissions from industrial output and from international transport. There are 
several notable patterns here. First, there is a significant difference between the output share of emissions and the trade share of emissions. North America and Europe are together responsible for just over a third of output emissions but over 60 percent of transport emissions. The US alone is responsible for almost a third of world emissions from transportation of exports. The opposite pattern holds for China, which is responsible for 20.8 percent of output emissions, and only 3.5 percent of transport emissions from exports. Second, for many regions there is a large imbalance between international transport emissions in imports and exports. The US export emissions share is much larger than its import emissions share while this imbalance is reversed from the European and East Asian perspective.

To some extent these shares are driven by the size of each region, reliance on trade, and trade imbalances. To eliminate these effects, in the remaining columns we calculate emission intensities for exports and imports, measured in grams of $\mathrm{CO} 2$ equivalent per dollar of trade. To make the numbers comparable, both output and transport emissions are reported as weighted averages of country x sector emissions, where the weights in each case reflect trade shares. ${ }^{17}$ Here we see large differences between regions in the emission intensities of output and transport. There is significant variation in output intensities, driven largely by the commodity composition of trade. South America, Oceania and the Middle East/Africa have very high output emissions per dollar of trade, driven by their reliance on emission intensive commodity production. Manufacturing oriented exporters see much smaller output intensities. Perhaps more surprising there are also very large differences in the transport intensities. The transportation of US exports is nearly eight times more emission intensive than the transportation of Chinese exports, and six times more emission intensive than Europe. This is a consequence of an unusually large reliance on air cargo in US exports.

\footnotetext{
${ }^{17}$ By using trade shares, the importance of a particular sector is the same for both output and transport emissions. Were we to use output shares for output, goods with a large share of output but a small share of trade would skew the averages.
} 
These numbers make clear that including transport significantly changes our perspective on which regions have emission intensive trade. India's production of traded goods has 143 percent more emissions than the US per dollar of trade, but after incorporating transportation, its exports are less emission intensive in total. We also see a strong imbalance in emission intensities. East Asian imports are much more emission intensive than the exports, while the reverse is true for the US.

A significant advantage of our approach to assessing transport emissions is that it gives us the ability to sort out which regions are engaged in especially emission intensive trade. A clear implication of these numbers is that both production and transportation emissions should be considered when evaluating policy changes designed to curtail emissions. In some countries the impact will be felt most acutely on the production side, whereas in countries like the US, the main effect will primarily be on transport. Similarly, in some climate change mitigation proposals, international transport emissions are to be included as part of a country's carbon allocation. The large differences between import and export emissions shown in Table 4 suggest the precise manner in which this is done could be very important. That is, North America would much prefer an import based allocation rather than an export based allocation, while East Asian countries would prefer the opposite.

\section{Reallocating Production: Does More Trade Mean More Emissions?}

A central question of the previous literature on trade and carbon emissions is this: will rising trade lead to higher or lower emissions? If two countries engaged in trade have similar output emission intensities, then more trade means more international transport and higher emissions. However, if the difference in output emissions is large enough to offset the transport emissions, trade could lower emissions.

This question has been previously addressed with case studies (Jones, 2006; Sims et al., 2007; Williams, 2007) or with largely imputed data (Peters and Hertwich, 2008). We can use our 
data to address it comprehensively. To begin we provide a straightforward partial equilibrium calculation. We look at all possible reallocations of production in which a country reduces domestic production of a sector and imports the same value of the good from abroad. Denoting the exporter or origin as " $o$ ", the destination country as " $d$ ", and the good " $g$ ", we can calculate the change in emissions associated with consuming the good as

$$
\Delta e_{o d g}^{c}=\left(e_{d g}^{Y}-e_{o g}^{Y}\right)+e_{o d g}^{T}
$$

We will consider all possible reallocations over all country pairs, which means that the first term in brackets will be symmetrically distributed around zero. (For example, there are two observations for the US and China trading electronics, one in which the US is the origin, and another in which China is the origin.) The question can then be framed as: is the variation in output emissions large or small relative to transport emissions, and what fraction of reallocations could reduce emissions despite incorporating transport?

In Figure 3a we provide a histogram of 29,300 production reallocations, with units in grams of $\mathrm{CO} 2$ per dollar traded.18 The median reallocation from trade increases emissions by 123 grams per dollar traded, while the mean reallocation increases emissions by 554 grams. Negative observations represent a reduction in emissions from trade; $26.5 \%$ of all possible reallocations reduce emissions, and these trade pairs account for about 31 percent of world trade by value in 2004.

To understand the mechanics of this reallocation better, we provide a similar distribution for two illustrative sectors: wearing apparel and bulk agriculture. For wearing apparel, there are quite small differences across countries in output emissions. This means that rising trade acts primarily to increase emissions from transport. Only $15.8 \%$ of production reallocations reduce emissions, and the aggregate changes in emissions from trade are quite small (mean 136). In contrast, there are large differences across countries in output emissions from bulk agriculture, and

${ }^{18}$ We drop the top and bottom $5 \%$ of values to eliminate outliers that distort the histogram. 
as we noted in Figure 2, transport is a small share of trade-related emissions. In this case, 41.6 percent of production reallocations reduce emissions, and the aggregate change in emissions from trade is very large (mean 764 grams).

Table 5 provides data for each country and producing sector including the fraction of trade reallocations that are GHG emission reducing, and the average change in emissions from trade. High income countries tend to have low output emissions and intensively use airplanes in trade, and here, few trade exchanges are $\mathrm{CO} 2$ reducing. Low income countries have high output emissions and intensively use maritime transport. Here, more than half of trade reallocations are emission reducing.

These calculations are mechanically focused only on GHG emissions, and do not address whether any particular trade flow is likely to take place. As such they are meant to be illustrative of the capacity of the trading system to increase or decrease emissions, but not the feasibility of the change. In the next section we consider general equilibrium shocks to the trading system in order to analyze how likely future patterns of trade growth will affect emissions.

\section{Trade Growth and Changes in International Transport Emissions}

The emission intensity of individual trade flows varies dramatically depending on what product is being traded, which countries are trading, and how they are transporting it. As a consequence, trade growth that also changes the composition of trade can result in pronounced differences in trade-related emissions.

In this section we will use a CGE simulation to generate changes in the value and composition of trade resulting from tariff liberalization and GDP growth. Combining this with our scale vs. intensity decomposition we can calculate the effect of growing trade on emissions growth. Fixing the emission intensity of a particular output sector $o-g$, the growth in output related emissions is: 


$$
\Delta E_{o g}^{Y}=\Delta Y_{o g} * e_{o g}^{Y}
$$

Fixing the emission intensity of a particular o-d-g trade flow, the growth of trade-related emissions is then

$$
\Delta E_{\text {odg }}^{T}=\Delta V A L_{\text {odg }} * e_{\text {odg }}^{T}
$$

This exercise holds fixed the modal shares for each $o-d-g$ flow, and the emission intensity of each mode. Put another way, this exercise takes the transportation system as given and examines how changes in trade affect the greenhouse gas emissions from international output and transport. We do not model how changes in fuel prices, spurred either by rising demand for fuel or changes in carbon/fuel taxes, affect mode-specific prices. Nor do we explicitly examine endogenous technological change in transportation, although we do explore sensitivity of our results to assumptions on the fuel and emission intensity of air transport. One can imagine an additional exercise, motivated by and made possible by the data constructed in this paper, focused on the effect of carbon taxation on fuel prices and therefore modal choice, and how that would feedback into changes in trade patterns. We leave this considerably more involved exercise for future work. Our approach of fixing modal shares for each $o-d-g$ flow yields a reasonable approximation of aggregate changes in modal use and emissions in two cases. One, if tariff liberalization or GDP growth does not generate large changes in relative transportation prices (e.g. the price of air relative to ocean shipping), then we would not expect modal shares within an $o-d-g$ flow to change much. This would be the case if there are few aggregate changes in modal use, or if trade growth does not affect input costs differentially across modes. Two, suppose that modal use varies primarily across (rather than within) $o-d-g$ flows due to immutable geography, infrastructure, and product characteristics. For example, land-adjacent countries will continue to move goods via road and rail independent of ocean shipping prices while countries separated by an ocean will be unable to use road and rail. Similarly, product weight will force grain onto bulk cargo carriers regardless 
of the price of air cargo. In these cases, small changes over time in modal use within each $o-d-g$ flow will be swamped by changes in the trade shares of flows that use one mode more than another. ${ }^{19}$

\section{A. Simulated Trade Growth}

We wish to simulate the changes in worldwide output and trade ( $\Delta Y_{\text {og }}$ and $\triangle V A L_{\text {odg }}$ in equations (7) and (8) respectively) associated with various tariff liberalization and output growth scenarios, which requires the use of a computable general equilibrium (CGE) model of trade. We employ version 7 of the GTAP model, aggregating the model to 40 regions and 23 traded and 6 non-traded goods. A highly detailed description of this widely used model can be found in Hertel and Tsigas (1997). We briefly summarize key characteristics here.

Within each sector firms are constant returns to scale with a production structure that is Leontief in factor inputs (labor, capital, and land) and intermediate inputs including energy commodities. Substitution between factor inputs is governed by a CES structure, as is substitution between intermediate inputs that are Armington differentiated by origin. On the consumption side, households have Cobb-Douglas preferences over consumption, government spending and saving. Demands over consumption goods employ a CDE (constant difference of elasticities) form, and households regard the output of each source country as Armington differentiated.

To capture possible effects of trade liberalization we explore four scenarios. There have been a wide variety of liberalization proposals as part of the Doha round of the WTO talks. We choose a representative three, referred to in Minor (2006) as Doha Scenarios 4, 5, and 9, because their design is closest to the proposals currently under consideration. Appendix 3 contains detailed notes on these scenarios. In summary, scenarios 4 and 5 focus on agricultural market access only with tariff cuts for developed countries ranging from 40 to 60 percent, and those for developing countries being one third smaller. Scenario 9 accounts for both agricultural and non-agricultural market access (NAMA), and here non-agricultural tariffs are cut progressively, i.e. peak tariffs are

${ }^{19} \mathrm{We}$ also hold fixed the wv ratio of trade for a given flow, assuming that small changes over time in wv within an o-d-g flow will be swamped by changes in the trade shares of light versus heavy flows. 
cut more than lower tariffs. In a final "full liberalization" scenario, all import and export tariffs and subsidies are set to zero.

Tariff liberalization may lead to modest increases in trade, but rising output is likely to lead to much more rapid trade growth. Moreover, output growth is likely to be asymmetric with some developing countries such as China and India growing much faster than developed countries. To experiment with output growth we use a specialized version of the GTAP model called GDyn (or Dynamic GTAP). This version of the model contains detailed projections of GDP and factor endowment growth rates from 2004-2020 for each country in the database (Walmsley 2006).20 This model takes both real GDP growth and factor input growth as exogenous (values shown in Appendix Table A4), and allows a Hicks neutral technological change variable to reconcile these changes with other model values.

This simulation allows us to examine two key points. First, predicted GDP growth rates vary widely across countries, with especially rapid growth in China and India, and slower growth in developed European economies. Second, this growth occurs through uneven rates of factor accumulation, with some countries rapidly accumulating capital and skilled labor while others see relatively rapid growth in unskilled labor. This allows us to model changes in both the scale of each economy and in comparative advantage arising from changing factor supplies.

\section{B. Results}

Table 6 summarizes the changes in output, exports, modal use (by value and by KG-KM), and CO2 emissions under each of the five scenarios. Changes in output value, output emissions, and export values come directly from the GTAP model. Combining these with our data on trade weight/value

\footnotetext{
20 Walmsley 2006 in turn builds GDP and input growth estimates based on Global Economic Prospects 2005, Ahuja and Filmer 1995, and CPB 1999. GDyn explicitly models the dynamics of capital accumulation, which makes it easier for the modeler to hit a given GDP growth target. It allows for international capital mobility so that closing the model requires us to allow investment to vary endogenously in one country (we chose South Africa, given its relative unimportance for the major issues at hand). The result was an unrealistically high rate of capital accumulation in South Africa. However all results are robust to including/excluding South Africa, except for those in Table 7.
} 
and distance we calculate changes in exports by weight and by transportation services. Combining changes in transportation services with data on modal use and emissions we calculate changes in modal use and emissions. For robustness we calculate changes in transport intensity assuming both a HIGH emissions scenario (aviation emissions matching the US cargo fleet), and a LOW emissions scenario (aviation emissions corresponding to the most efficient long range planes, and matching 2004 total emission values from the ITF).

The three Doha scenarios are largely uninteresting from a transport and emissions perspective. Simply, these liberalization efforts are so modest that they yield little growth in trade, in transport, or in emissions. The most far-reaching scenario yields a 1.1 percent increase in trade (by value or KG-KM), and a slightly higher (1.7-2.1 percent) rise in transport emissions. The full liberalization scenario eliminates all import and export tariffs. While this is not currently on the negotiating agenda, it is an interesting exercise because it reveals an important intersection between the structure of protection and emissions. Tariff rates are not set uniformly across trading partners and significant preferences are given to partners within trading blocs such as the EU and NAFTA. Because trading blocs tend to be geographically concentrated, tariffs are lower for more proximate partners and especially for land-adjacent partners. In our base year, the trade-weighted average tariff rate for land-adjacent partners is 1 percent, while the average tariff for non-adjacent partners is 5.5 percent. This is an important phenomenon from a transportation perspective because rail and road transport dominate international trade between land-adjacent countries. Tariff liberalization that removes tariff preferences for land-adjacent countries will then shift trade toward distant partners and away from road and rail transport.

These effects show up clearly in our results. In Table 6 we see that full liberalization increases trade by 6 percent, concentrated in those products (agriculture, textiles and wearing apparel) that are subject to the highest rates of protection. ${ }^{21}$ International transport emissions rise

\footnotetext{
21 The small negative effect on output value is due to terms of trade effects. Real quantities of trade rise.
} 
faster than trade, due in part to a rise in trade at a distance and in part to an expansion of emission intensive air cargo. As we see in Table 6, rail and road usage shrinks substantially while international aviation and maritime transport grow quickly.

In contrast to the tariff liberalization simulations, the GDP growth scenario yields profound changes in output, trade, and greenhouse-gas emissions. Output and trade value rises at similar rates, accumulating to 75-80 percent growth over this period. Trade measured by transport services (KG$\mathrm{KM}$ ) rises much faster, 6.5 percent per annum, accumulating to 173 percent growth. Not surprisingly then, transport emissions rise faster than output and trade by value, and faster than output emissions.

To understand this, note that tariff liberalization created trade growth biased toward long distance trade because of the erosion of proximity-based tariff preferences. The GDP growth experiment creates trade growth biased toward long distance trade because the fastest growing countries (China, India) are far away from other large markets. As with tariff liberalization there is faster growth in air and sea transport relative to rail and road transport.

These aggregated numbers hide a wealth of interesting variation we wish to explore. Recalling equation (8), we ask: what is the relationship between transport emission intensity in the base year, and the subsequent growth in trade? In the top left panel of Table 7 we group 30,906 o- $d-g$ trade flows into quartiles using transport emission intensity, and assign each $o-d-g$ observation a quartile dummy variable. ${ }^{22}$ We then regress trade growth (by $o-d-g$ ) on emissions quartiles with the constant representing growth in the lowest emission quartile. In both the full liberalization and GDP growth scenarios, the higher the transport emission intensity of the trade flow the faster trade grew. This effect was considerably stronger in the GDP growth scenario, both in the size of the coefficients and in the regression R-squared. In the bottom left panel we examine correlates of

\footnotetext{
22 We also omit the GAS sector and incorporate fixed effects for South Africa. GAS is an outlier that skews results badly because its weight/value ratio and transport modal use are poorly measured. For technical reasons noted above South Africa is treated differently in the model closure, which results in unrealistic measures of capital growth.
} 
transport emission intensities. Trade growth in both scenarios is fastest for trade flows that occur over longer distances, and use a higher share of air cargo, and in products with higher weight/value ratios.

The top right panel of Table 7 performs a similar exercise on output emissions. For each of 879 origin-products we group production into quartiles based on output emission intensities, and regress output growth on these quartiles. Full liberalization has very little effect in reorienting output growth toward more or less emission intensive production. However, GDP growth orients output growth toward those countries and products with high output emissions. This is primarily the effect of rapid GDP growth in China and India. Because their output is more emission intensive (in the fourth quartile of intensities), more rapid GDP growth in those countries will push overall emissions higher.

\section{Conclusions and Implications}

Most of the work on trade and climate change has ignored international transportation, or considered it in the context of case studies. This neglect is due in part to a lack of data, and in part to the belief that international transportation represents a small portion of overall emissions. In this paper we combined data on trade, transportation modes, transport emissions, and output emissions to calculate the contribution of transportation to trade-related greenhouse gas emissions in the aggregate and for all trade flows world-wide. While international transportation is a small fraction of overall emissions it is a surprisingly large fraction of trade-related emissions. Twothirds of trade-related emissions in US exports are due to international transportation, and worldwide over 75 percent of the trade-related emissions of transport equipment, electronic equipment, machinery, and manufactures nec come from transportation.

We used our data to systematically evaluate whether increasing trade could be emission reducing. If a country has very high output emissions, and transports goods efficiently, importing 
the good from a low emission producer can reduce emissions. We find that in one quarter of possible production reallocations, trade can reduce emissions. Emission reducing trades are more likely to occur in agriculture and mining sectors while reducing emissions through trading manufactures is relatively difficult.

These reallocations are simple partial equilibrium changes and do not address whether such a reallocation would be feasible or likely. To examine likely changes we combined our data with a series of trade growth simulations designed to illuminate the role of tariff liberalization and GDP growth. Tariff liberalization undoes tariff preferences that favor proximate and land-adjacent partners who use rail and road transport and move goods short distances. This results in a shift in trade toward distant partners, a more intensive use of air cargo, and transport emissions growth that is more rapid than trade growth. The share of transport in trade-related emissions rises, reversing a downward trend created by preferential trade agreements. However, these changes are small relative to those caused by GDP growth in China and India. We project transport emissions rising at 5 percent a year as economic growth in these countries significantly increases the distance of trade.

A clear implication of our calculations is that production and transportation emissions should be considered when evaluating policy changes designed to curtail emissions. Many exporters and products that look relatively "clean" when we focus only on output emissions are in fact heavy emitters once incorporating transportation. In some countries the impact of mitigation will be felt most acutely on the production side, whereas in countries like the US, the main effect will primarily be on transport.

There are also significant implications for mechanism design, specifically, how to treat the international transport sector within the global framework for emissions. Does international transport "belong" to the exporter, to the importer, or should it be treated as a separately capped sector, in essence a country unto itself? Given the imbalance in transport emissions the US would 
much prefer an import based allocation rather than an export based allocation, while East Asian countries would prefer the opposite. Were transport treated as a separately capped "country" the higher rate of transport services growth (and the differences in growth rates across modes) would yield potentially large distortionary effects on trade as caps bind faster on transport than on output. Finally, our trade and emissions growth calculations take the transport sector as given and as such abstract from important substitution margins. We assume away changes in modal usage within a particular trade flow over time, and do not allow for technological change in emission intensities due either to innovation or to updating the vintage of the transportation fleet capital stock. Including these additional margins of response is beyond the scope of the current study, but in future work this could be useful for understanding interactions between trade, transportation and emissions. In particular, the much higher fuel intensity of air cargo, and its associated CO2 emissions, suggests that climate mitigation policies could have pronounced effects on how goods move and the kinds of goods that nations trade. This is especially important for countries like the US, whose reliance on air cargo results in unusually high transportation emissions.

\section{References}

Aircraft Economics, 1999. Freighter Cost Comparisons. Aircraft Economics, 45, 50-56.

Ahuja, V. and Filmer, D., 1995. "Educational Attainment in Developing Countries; New Estimates and projections Disaggregated by Gender," World Bank Policy Research Working Paper 1489.

Babiker, M., 2005. Climate Change Policy, Market Structure and Carbon Leakage. Journal of International Economics, 65(2), 421-445.

Berthelon, M., and Freund, C., 2008. “On the Conservation of Distance in International Trade”. Journal of International Economics, 75, 310-20.

Cadarso, M.-A., Lopez, L.-A., Gomez, N., Tobarra, M.-A., 2010. $\mathrm{CO}_{2}$ Emissions of International Freight Transport and Offshoring: Measurement and Allocation. Ecological Economics 69, 1682-1694.

California Climate Change 2006. Comparing Energy Options.

Canals, L. M., Cowell, S.J., Sims, S. and Besson, L., 2007. Comparing Domestic versus Imported 
Apples: A focus on Energy Use. Environmental Science and Pollution Research, 14 (5), $338-344$.

Carlsson-Kanyama, A., Pipping Ekstrom, M. and Shanahan, H., 2003. Food and life cycle energy inputs: consequences of diet and ways to increase efficiency. Ecological Economics, 44, 293-307.

Copeland, B. R. and Taylor, M.S., 2004. Trade, Growth, and the Environment. Journal of Economic Literature 42 (1), 7-71.

CPB, 1999. "WorldScan: the Core Version," CPB Netherlands Bureau for Economic Policy Analysis.

De, Prabir, 2007. Facilitating Overland Trade in South Asia. mimeo.

Disdier, A.C. and Head, K., 2008. "The Puzzling Persistence of the Distance Effect on Bilateral Trade". The Review of Economics and Statistics, 90(1), 37-41.

Ederington, J. and Minier, J., 2003. Is environmental policy a secondary trade barrier? An empirical analysis. Canadian Journal of Economics, 36 (1), 137-155.

EEA. 2007. “EMEP/CORINAIR Emission Inventory Guidebook”, Group 8.

Giannouli, M., and Mellios, G., 2005. Overall Energy Efficiency and specific $\mathrm{CO}_{2}$ emissions for passenger and freight transport. European Environmental Agency, TERM 200527 EEA 32.

Grether, J.-M., Mathys, N. A., de Melo, J., 2010. Global Manufacturing $\mathrm{SO}_{2}$ Emissions: Does Trade Matter?. Review of World Economics 145(4), 713-729.

Hertel, T. and Tsigas, M., 1997. The Structure of GTAP. GTAP Working Paper 413.

Hummels, D. L., 2009. "Globalization and Transport Costs”. Study Prepared for OECD International Transportation Forum Meetings.

Hummels, D.L. and Schaur G., 2011. “ Time as a Trade Barrier”. Mimeo.

International Transport Forum, 2010. Transport Greenhouse Gas Emissions 2010. ITF/OECD.

International Energy Agency, 2010. Co2 Emissions from Fuel Combustion 2010. IEA/OECD.

IPCC/OECD/IEA. 1997. Revised 1996 IPCC Guidelines for National Greenhouse Gas Inventories. Paris: Intergovernmental Panel on Climate Change (IPCC), Organization for Economic Co-operation and Development (OECD), International Energy Agency (IEA).

Jones, A. , 2006. A life cycle analysis of UK supermarket imported green beans from Kenya. Fresh Insights No. 4. International Institute for Environment and Development, London, United Kingdom.

Kristensen, H.O., 2006. Cargo Transport by Sea and Road - Technical and Environmental Factors. Naval Engineers Journal, 118, 115-129. 
Lee, H.-L., 2008. The Combustion-based CO2 Emissions Data for GTAP version 7 Data Base. GTAP Working Paper 4470.

Levinson, A., 2009. Technology, International Trade and Pollution from US Manufacturing. American Economic Review, 99(5), 2177-2192.

Levinson, A. and Taylor, M., 2008. Unmasking the Pollution Haven Effect. International Economic Review, 49(1), 223-253.

Maersk Line, 2007. Constant Care for the Environment.

Miljøstyrelsen Miljøministeriet (Danish Environmental Protection Agency, Danish Ministry for the Environment), 2003. "Greenhouse Gas Emissions from International Aviation and Allocation Options”. URL: http://www2.mst.dk/common/Udgivramme/Frame.asp?http://www2.mst.dk /udgiv/publications/2003/87-7972-489-2/html/helepubl_eng.htm.

Minor, P., 2006. Projected Impacts of the Doha Development Round on Egypt's Trade and Production. GTAP Working Paper 3363.

National Technical University of Athens Laboratory for Maritime Transport, 2008. Ship Emissions Study.

Olivier, J., Peters, J., 1999. International marine and aviation bunker fuel: trends, ranking of countries and comparison with national CO2 emissions. RIVM report 773301 002. National Institute of Public Health and the Environment (RIVM), The Netherlands.

URL: http://www.rivm.nl/bibliotheek/rapporten/773301002.pdf

Peters, G. P., Hertwich, E. G., 2008. $\mathrm{CO}_{2}$ Embodied in International Trade with Implications for Global Climate Policy. Environmental Science and Technology 42(5), 1401-1407.

Rose, S., Avetisyan, M. and Hertel, T., 2010. Development of the Preliminary Version 7 Non-CO2 GHG Emissions Dataset. GTAP Working Paper 4618.

Sim, S., Barry, M., Clift, R. and Cowell, S., 2007. The relative importance of transport in determining an appropriate sustainability strategy for food sourcing. A case study of fresh produce supply chains. International Journal of Life Cycle Assessment, 12, 422-431.

Transportation Research Board, 2009. “Guidebook on Preparing Airport Greenhouse Gas Emissions Inventories". Research sponsored by the Federal Aviation Administration.

USEPA, 2006. Global Emissions of Non- $\mathrm{CO}_{2}$ Greenhouse Gases: 1990-2020. United States Environmental Protection Agency (US-EPA), Washington, D.C., EPA Report 430-R-06-003.

Van Veen-Groot, D., Nijkamp, P., 1999. Globalization, transport and the environment: new perspectives for ecological economics. Ecological Economics 31, 331-346.

Walmsley, T., 2006. A Baseline Scenario for the Dynamic GTAP Model. GTAP Working Paper 2854.

Williams, A., 2007. Comparative study of cut roses for the British market produced in Kenya and the Netherlands. Précis Report for World Flowers, February.

World Bank, 2005. Global Economic Prospects 2005. 


\section{Appendix 1: Model Aggregation}

Region Aggregation: We begin with 113 constituent countries/regions available in the GTAP database, then aggregate into the 40 "regions" listed in bold. Some regions are single countries and others are aggregations of the 87 constituent countries available in the GTAP database.

\section{North America: (2 regions) Canada, United States}

Central America: (2 regions) Mexico, Other Central America and Caribbean (Central America, Rest of FTAA, Rest of Caribbean)

South America: (4 regions) Argentina, Brazil, Chile, Rest of South America (Colombia, Peru, Uruguay, Venezuela, Rest of Andean Pact, Rest of South America)

Europe: (18 regions) Austria, Belgium-Luxemburg, Denmark, Finland, France, Germany, Greece, Ireland, Italy, Netherlands, Portugal, Spain, Sweden, United Kingdom, Russia, Rest of European Union (Cyprus, Czech Republic, Estonia, Hungary, Latvia, Lithuania, Malta, Poland, Slovakia, Slovenia, Bulgaria, Romania), Other Europe - EFTA (Switzerland, Iceland, Liechtenstein, Norway), Other CEE and Other CIS (Albania, Croatia, Turkey, Rest of Former Soviet Union) South Asia: (2 regions) India, Other South Asia (Bangladesh, Sri Lanka, Afghanistan, Rest of South Asia)

\section{East Asia (8 regions) Japan, Korea, Singapore, Malaysia-Indonesia, China-Hong Hong,} Taiwan, Other East Asia (North Korea, Macau, Mongolia), Other South East Asia (Philippines, Thailand, Vietnam, Rest of Southeast Asia)

Middle East/Africa: (3 regions) South Africa, Middle East and North Africa (Middle East, Morocco, Tunisia, Rest of North Africa), Sub-Saharan Africa (Botswana, Malawi, Mozambique, Tanzania, Zambia, Zimbabwe, Madagascar, Uganda, Rest of South African Customs Union, Rest of Southern African Development Community, Rest of Sub-Saharan Africa)

Oceania Countries (1 region): (Australia, New Zealand, Rest of Oceania)

Sectoral Aggregation. GTAP provides data on 57 sectors. We aggregate these to 27 sectors, and focus on 23 tradable sectors described in Table A1 below. Manufacturing and mining sectors are analyzed using the same level of detail as in the GTAP data. Agricultural sectors are aggregated as follows.

Bulk Agriculture (Paddy rice; Wheat; Cereal grains nec; Oil seeds; Sugar cane, sugar beet; Plantbased fibers; Crops nec);

Processed Agriculture (Vegetables, fruit, nuts; Bovine cattle, sheep and goats, horses; Animal products nec; Raw milk; Wool, silk-worm cocoons; Bovine meat products; Meat products nec; 
Vegetable oils and fats; Dairy products; Processed rice; Sugar; Food products nec; Beverages and tobacco products);

\section{Appendix 2. Sources of Modal Data and Calculation of Modal Shares}

The table below summarizes the source of modal data for worldwide trade flows. X indicates that modal shares are directly observed from various data sources, as follows. These data represent $65 \%$ of the value of world trade.

$\mathrm{X}^{\mathrm{a}}$ Modal shares calculated using Eurostats data on European exports. For flows from EU15 to EU25 (excluding Bulgaria and Romania), modal shares are originally reported at the 3 digit level of the NSTR. These data were compiled on special request by statisticians at Eurostats. We apply the most recently available year, 1999.

$\mathrm{X}^{\mathrm{b}}$. Modal shares calculated from Eurostats data on European imports.

$\mathrm{X}^{c}$. Modal shares calculated using US “Imports of Merchandise”, US Bureau of the Census.

$\mathrm{X}^{\mathrm{d}}$. Modals shares calculated from ALADI trade data.

$\mathrm{X}^{\mathrm{e}}$. Modal shares calculated using US “Exports of Merchandise”, US Bureau of the Census.

Xf. Modal shares calculated using US “Exports and Imports of Merchandise" (US Bureau of the Census) and freight flows data from the North American Transborder Freight Data.

\begin{tabular}{|l|c|c|c|c|c|c|c|c|}
\hline \multicolumn{1}{|c|}{ Importer } & EU & US & LAC & $\begin{array}{c}\text { Rest of } \\
\text { Europe }\end{array}$ & $\begin{array}{c}\text { Canada, } \\
\text { Mexico }\end{array}$ & Asia & Africa & Other \\
\hline EU & $\mathrm{X}^{a}$ & $\mathrm{X}^{a}$ & $\mathrm{X}^{d}$ & $\mathrm{X}^{a}$ & $\mathrm{X}^{a}$ & $\mathrm{X}^{a}$ & $\mathrm{X}^{a}$ & $\mathrm{X}^{a}$ \\
\hline US & $\mathrm{X}^{b}$ & -- & $\mathrm{X}^{d}$ & $\mathrm{X}^{e}$ & $\mathrm{X}^{f}$ & $\mathrm{X}^{e}$ & $\mathrm{X}^{e}$ & $\mathrm{X}^{e}$ \\
\hline LAC & $\mathrm{X}^{b}$ & $\mathrm{X}^{c}$ & $\mathrm{X}^{d}$ & $\mathrm{~A} / 0$ & $\mathrm{~A} / 0$ & $\mathrm{~A} / 0$ & $\mathrm{~A} / 0$ & $\mathrm{~A} / 0$ \\
\hline Rest of Europe & $\mathrm{X}^{b}$ & $\mathrm{X}^{c}$ & $\mathrm{X}^{d}$ & $\mathrm{~L} / \mathrm{A} / 0$ & $\mathrm{~A} / 0$ & $\mathrm{~A} / 0$ & $\mathrm{~A} / 0$ & $\mathrm{~A} / 0$ \\
\hline Canada, Mexico & $\mathrm{X}^{b}$ & $\mathrm{X}^{f}$ & $\mathrm{X}^{d}$ & $\mathrm{~A} / 0$ & $\mathrm{~L} / \mathrm{A} / 0$ & $\mathrm{~A} / 0$ & $\mathrm{~A} / 0$ & $\mathrm{~A} / 0$ \\
\hline Asia & $\mathrm{X}^{b}$ & $\mathrm{X}^{c}$ & $\mathrm{X}^{d}$ & $\mathrm{~A} / 0$ & $\mathrm{~A} / 0$ & $\mathrm{~L} / \mathrm{A} / 0$ & $\mathrm{~A} / 0$ & $\mathrm{~A} / 0$ \\
\hline Africa & $\mathrm{X}^{b}$ & $\mathrm{X}^{c}$ & $\mathrm{X}^{d}$ & $\mathrm{~A} / 0$ & $\mathrm{~A} / 0$ & $\mathrm{~A} / 0$ & $\mathrm{~L} / \mathrm{A} / 0$ & $\mathrm{~A} / 0$ \\
\hline Other & $\mathrm{X}^{b}$ & $\mathrm{X}^{c}$ & $\mathrm{X}^{d}$ & $\mathrm{~A} / 0$ & $\mathrm{~A} / 0$ & $\mathrm{~A} / 0$ & $\mathrm{~A} / 0$ & $\mathrm{~A} / 0$ \\
\hline
\end{tabular}

The remaining values are estimated. A/O indicates that land transport is not available between regions, and so trade flows are split between air and ocean. L/A/O indicates that land (rail, truck), air, and ocean shares are imputed.

Modal Share Data Imputation: For trade flows representing 35 percent of world trade, no direct information on modal use is available. In these cases we estimate modal use by relying on the matrix of modal trade flows we do have and the following four-step algorithm.

1. Identify trade where land transport is infeasible. 
If an $o-d$ country pair is not on the same continent, or a destination could not reasonably be reached by land transport, rail and road shares are set to zero. (That is, Japan is part of Asia, but lacks a land bridge so its rail and road shares are zero.). Of the 35 percent of world trade not covered by our explicit modal share data, 33 percent have no land-based trade. For these cases, skip to step three.

2. Estimate the share of trade that moves by land.

For the 2 percent of world trade without modal data, and where land transport is an option, we proceed on a case by case basis. For European country pairs not covered explicitly by the EU data, we estimate a modal share model with first the rail share of trade and then the road share as a dependent variable. Regressors include fixed effects for origin, destination, and GTAP sector, the distance between countries, a dummy for land-adjacency, and the weight/value ratio of the exporter-sector. The sample employed is the EU data for which we do have modal information recall that all the EU 27 countries report their imports from all European countries and their exports to all European countries. We then use out of sample prediction to generate modal splits for the remaining countries. This allows us to estimate, for example, the share of rail in Russian exports of coal by calculating Russia's conditional average share of rail to the EU27 countries (the origin fixed effect), the weight/value of Russian coal, and the distance to each market.

This leaves intra-continental trade within Africa and land-adjacent Asian countries, roughly 1.8 percent of world trade by value. For Asia we use calculations by Prabir De (2007) that report the modal shares of Indian trade with its land-adjacent neighbors, summed over all products and partners. These shares do not vary over sectors. For intra-African trade (a vanishingly small share of world trade) we could find no data on modal shares and so imposed road shares of 75 percent and rail shares of 0 .

3. Split the (air+ocean) share

Recall that in almost all cases (33 percent of the 35 percent of trade with no data), the ocean + air share is $100 \%$. In the remaining 2 percent of cases we split air v. ocean for the trade that is leftover after subtracting off the shares of trade going to rail and road transport.

We estimate a model where the dependent variable is the ratio of air/ocean and the regressors include the weight/value ratio of the exporter-product, distance between markets, whether they are land-adjacent and vectors of fixed effects by origin, destination, and GTAP sector. These origin and destination fixed effects capture all market characteristics such as level of development, and quality and composition of infrastructure that strongly affect this modal split. The product fixed effects absorb factors that explain modal use such as bulk, spoilage, the need for special packing, and timely delivery. Again, the estimation sample includes the EU, US, and ALADI data for which we 
have explicit modal share data and we use out of sample prediction to generate modal splits for the remaining countries. The high R2 in these regressions (0.75) suggests that the model does a good job of identifying share variation.

\section{Appendix 3: Simulating Trade Growth: Tariff Liberalization Scenarios}

To capture possible effects of trade liberalization we explore four scenarios. Three of these are "likely" tariff cuts under current Doha round negotiations. The fourth is a full liberalization scenario in which all import and export tariffs and subsidies are set to zero.

There have been a wide variety of liberalization proposals as part of the Doha round. Ten of these proposals have been modeled by CEPII and incorporated into the GTAP model. There are subtle differences across these proposals, so we choose a representative three, referred to in Minor (2006) as Doha Scenarios 4,5, and 9. Scenarios 4 and 5 focus on agricultural market access only, while scenario 9 accounts for both agricultural and non-agricultural market access (NAMA). These scenarios are chosen because their design is closest to the proposals currently under consideration. Scenario 4 and 5 are both based on the Harbinson proposal, which consists of applying proportional tariff cuts on four tiers of tariff ranges. Tariff ranges and cuts in each tier vary between developing and developed countries. The table below is taken from Minor (2006) and shows the Harbinson tiered tariff cutting formula for agriculture in scenario 4. The tariff cuts are highest for developed countries ranging from 40 to 60 percent. Developing countries tariff cuts in each tier are about two thirds those in the corresponding tiers of developed countries.

\begin{tabular}{l|c|c|c|c}
\hline Tier & \multicolumn{2}{|c|}{ Developed Countries } & \multicolumn{2}{c}{ Developing Countries } \\
\hline & $\begin{array}{c}\text { Tariff Rate } \\
\text { Range (\%) }\end{array}$ & Cut (\%) & $\begin{array}{c}\text { Tariff Rate } \\
\text { Range (\%) }\end{array}$ & Cut (\%) \\
\hline $\mathbf{1}$ & $<15$ & 40 & $<20$ & 25 \\
\hline $\mathbf{2}$ & $15-90$ & 50 & $20-60$ & 30 \\
\hline $\mathbf{3}$ & $>90$ & 60 & $60-120$ & 35 \\
\hline $\mathbf{4}$ & -- & -- & $>120$ & 40 \\
\hline \hline
\end{tabular}

Scenario 5 is the same as scenario 4 but allows countries to avoid the application of the tariff cuts on $2 \%$ of sensitive products. In practice, the chosen exceptions are concentrated in processed agriculture'. Scenario 9 adds non-agricultural market access. ${ }^{23}$ The non-agricultural tariff cuts are

${ }^{23}$ The agricultural market access underlying this scenario assumes instead of the Harbinson formula a harmonizing formula. 
non-proportional, so that peak tariffs are reduced more than lower tariffs. Non-linear tariff cuts formulas are usually referred as Swiss-type. While the adoption of Swiss-type formula on nonagricultural products is agreed among negotiators the exact type is not. Our scenario assumes the Girard (WTO 03-4322) formula:

$T_{1}=\frac{B \times T_{a} \times T_{0}}{B \times T_{a}+T_{0}}$

Where $T_{1}$ is the new bound tariff rate, $B$ is the coefficient to be determined for reductions, $T_{0}$ is the base bound rate, and $T_{a}$ is the average of base bound rates for NAMA products. $B$ is equal to 1 for developed countries and 2 for developing countries. 


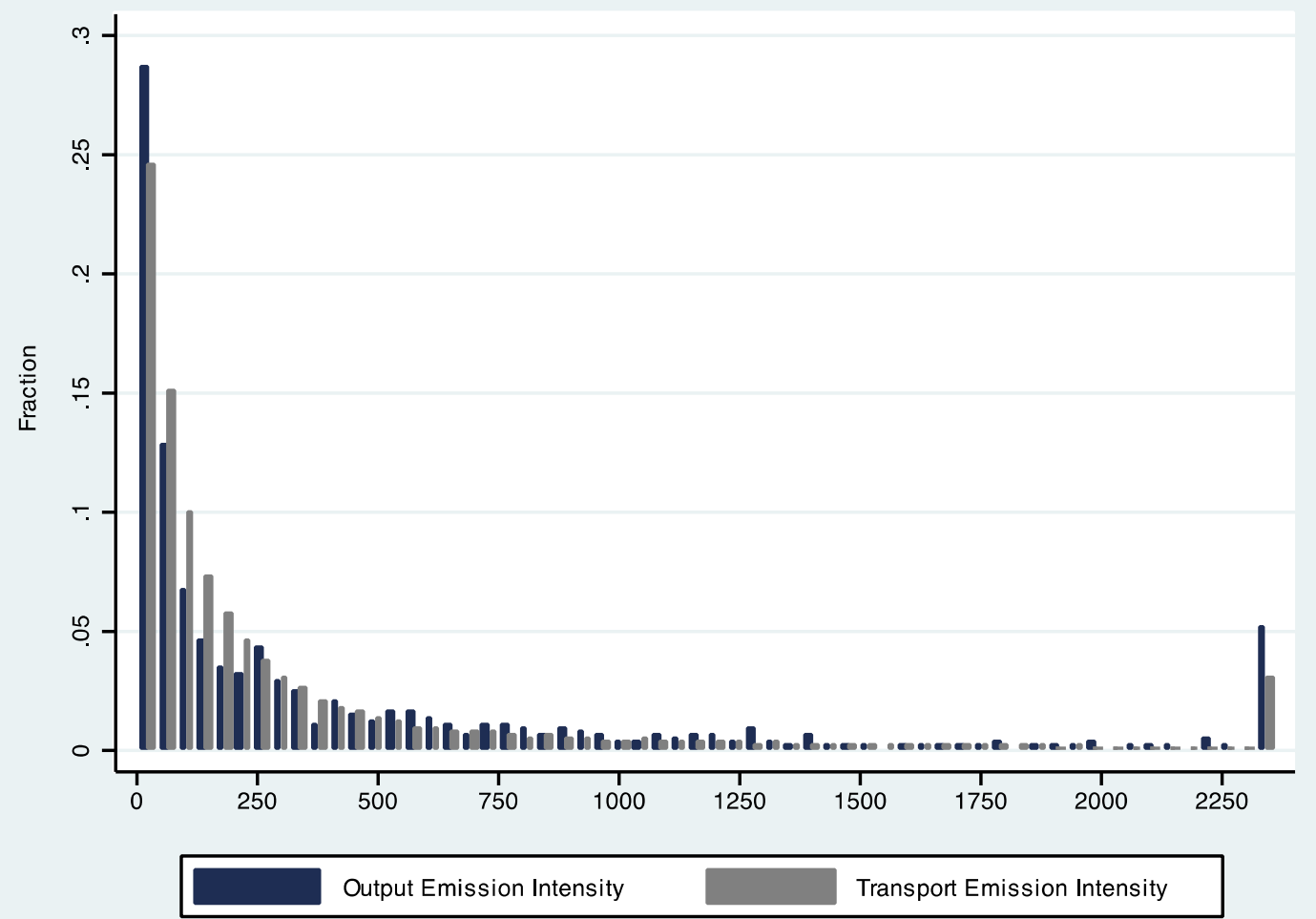

Note. Emissions intensities are expressed in grams of $\mathrm{CO} 2$ per dollar.

Figure 1. Distribution of Emission Intensities 


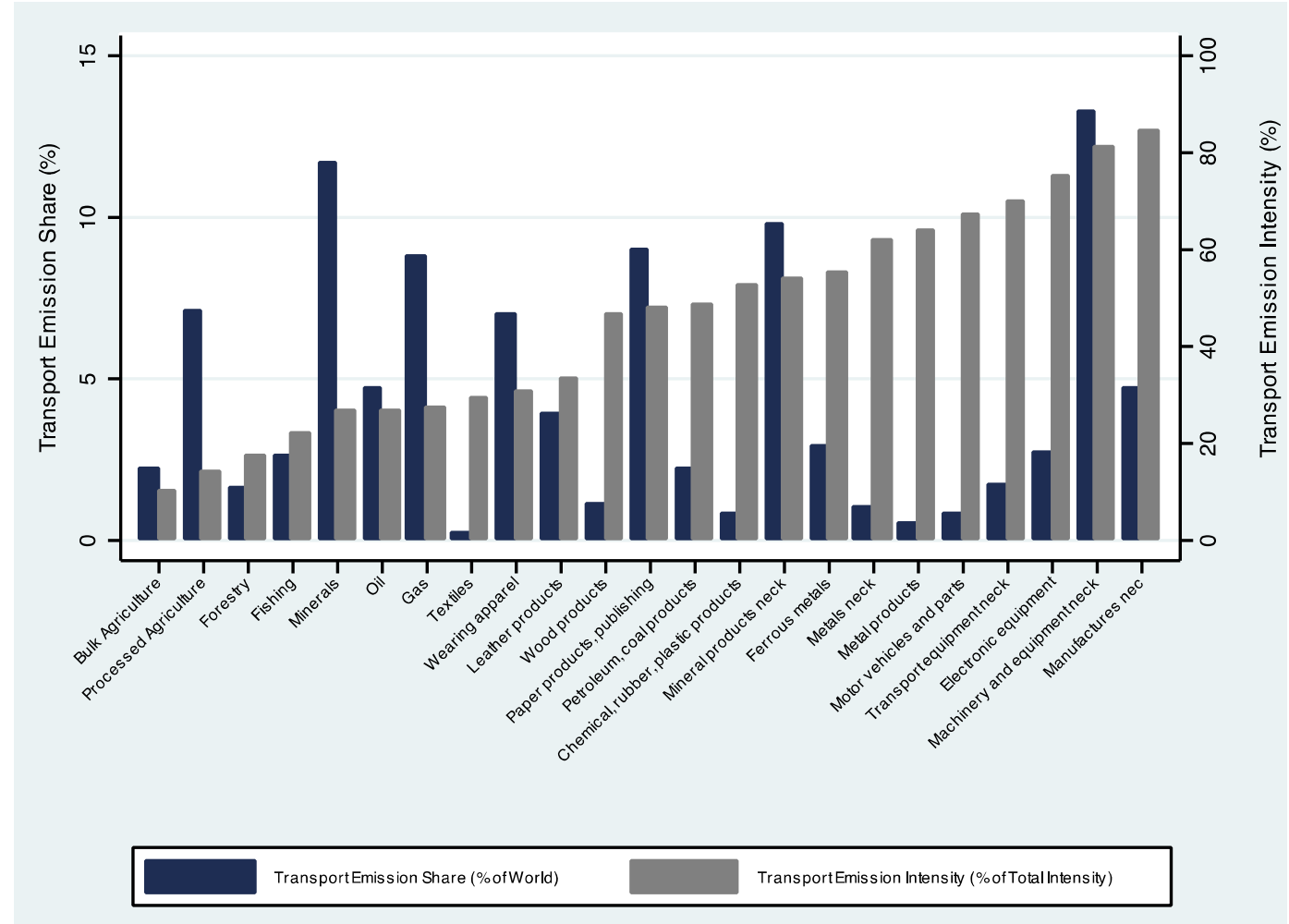

Note. Emissions intensities are expressed in grams of $\mathrm{CO} 2$ per dollar.

Figure 2: The Contribution of Transport to Total Trade-Related Emissions 


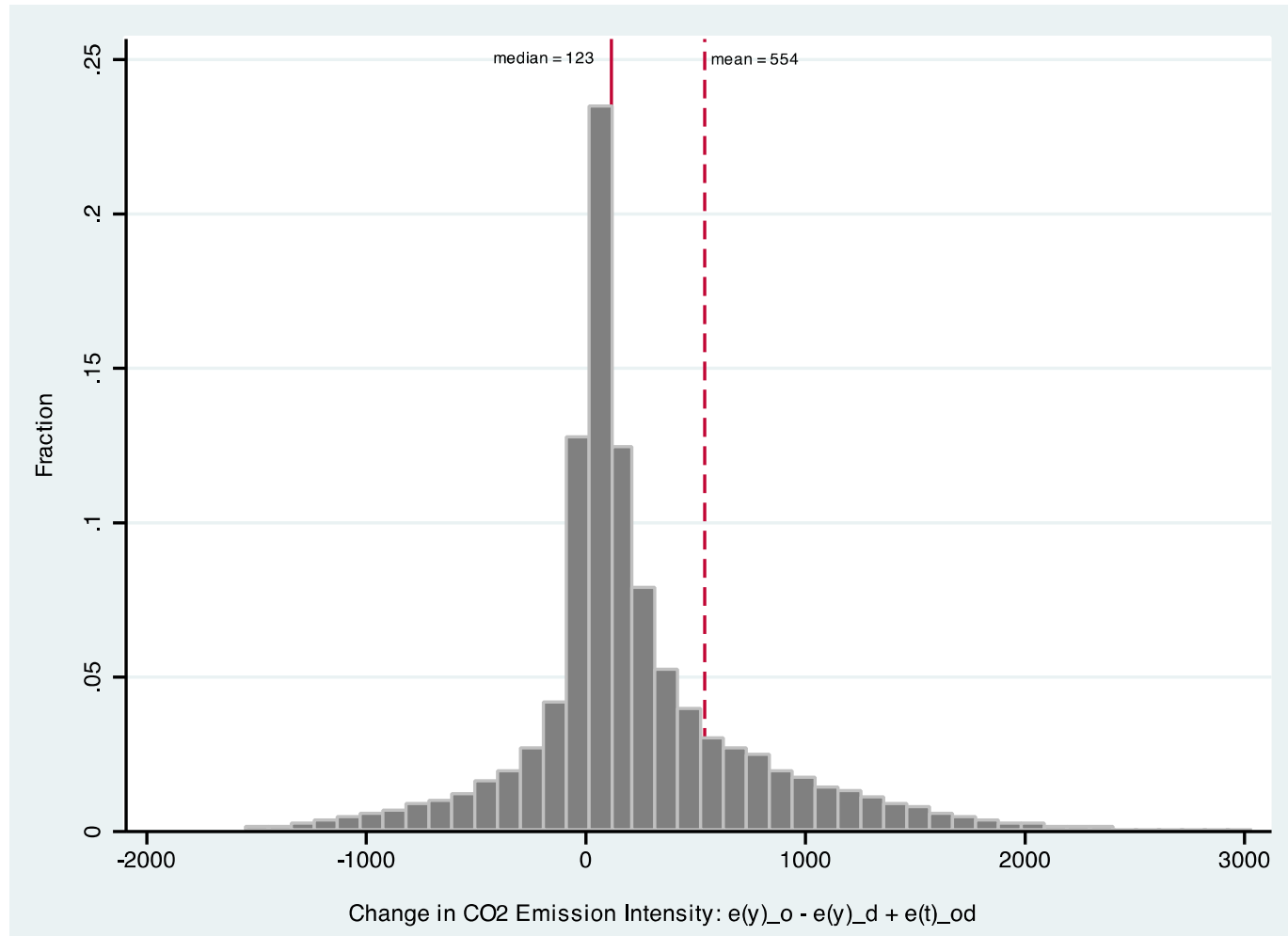

Note: $26.5 \%$ of all origin-destination-sector trade flows lead to a reduction in total $\mathrm{CO} 2$ emission (output and transport emissions combined). Emission intensities are expressed in grams of CO2 per dollar

Figure 3a: Net Change in CO2 Emissions due to Trade
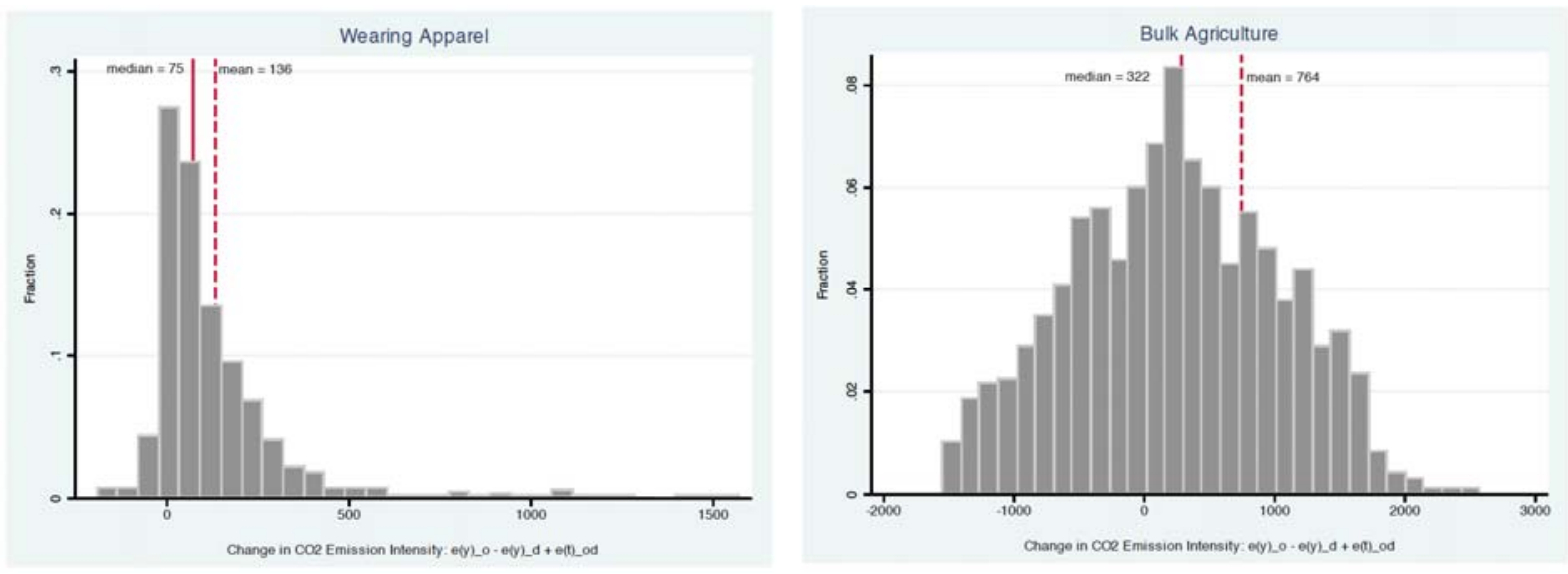

Note. Emission intensities are expressed in grams of $\mathrm{CO} 2$ per dollar.

Figure 3b: Net Change in C02 Emissions for Selected Sectors 
Table 1. World Output and Transport Emissions, 1990-2004 (selected years)

\begin{tabular}{lrrrr}
\hline \hline & $\mathbf{1 9 9 0}$ & $\mathbf{1 9 9 5}$ & $\mathbf{2 0 0 0}$ & $\mathbf{2 0 0 4}$ \\
\hline C02 Emissions (mil tons Co2) & & & & \\
\hline Fuel combustion, all sources $^{1}$ & 21024 & 21808 & 23487 & 26320 \\
Total Transport $^{1}$ & 4614 & 5047 & 5678 & 6202 \\
International Transport (aviation, maritime) $^{2}$ & 649 & 710 & 829 & 910 \\
\hline \hline International Transport Emissions & & & & \\
\hline Share of Total Emissions & $3.1 \%$ & $3.3 \%$ & $3.5 \%$ & $3.5 \%$ \\
Share of Transport Emissions & $14.1 \%$ & $14.1 \%$ & $14.6 \%$ & $14.7 \%$ \\
CO2 equivalent grams per Dollar of Exports & 158.8 & 129.6 & 104.0 & 93.3
\end{tabular}

Note. ${ }^{1}$ Source: International Energy Agency. ${ }^{2}$ International transport includes international maritime and aviation transport modes. Data source: International Transport Forum 
Table 2. Regional Modal Shares, by trade value and KG-KM

\begin{tabular}{|c|c|c|c|c|c|c|c|c|}
\hline \multicolumn{9}{|c|}{ Panel (A) Modal shares by importer } \\
\hline & By Value & & & & By KG-KM & & & \\
\hline & Sea & Air & Rail & Road & Sea & Air & Rail & Road \\
\hline North America & 46.6 & 21.0 & 6.7 & 25.7 & 91.8 & 1.4 & 1.4 & 5.5 \\
\hline Central America & 78.8 & 16.3 & 0.3 & 4.6 & 97.9 & 0.6 & 0.1 & 1.4 \\
\hline South America & 66.4 & 22.7 & 0.3 & 10.6 & 96.0 & 1.3 & 0.2 & 2.6 \\
\hline Europe & 35.5 & 13.0 & 4.5 & 46.9 & 91.7 & 1.1 & 2.0 & 5.2 \\
\hline South Asia & 74.8 & 21.7 & 0.6 & 2.9 & 99.2 & 0.5 & 0.1 & 0.3 \\
\hline East Asia & 72.8 & 25.8 & 0.2 & 1.2 & 98.8 & 1.1 & 0.0 & 0.1 \\
\hline Middle East/Africa & 68.2 & 19.1 & 0.0 & 12.7 & 88.5 & 0.9 & 0.0 & 10.6 \\
\hline Oceania & 78.0 & 22.0 & 0.0 & 0.0 & 98.1 & 1.9 & 0.0 & 0.0 \\
\hline WORLD & 50.2 & 18.4 & 3.5 & 27.8 & 95.0 & 1.1 & 0.8 & 3.1 \\
\hline \multicolumn{9}{|c|}{ Panel (B) Modal shares by exporter } \\
\hline North America & 28.3 & 25.9 & 9.4 & 36.4 & 88.2 & 4.6 & 1.4 & 5.8 \\
\hline Central America & 74.0 & 20.6 & 0.4 & 5.0 & 97.0 & 0.9 & 0.2 & 2.0 \\
\hline South America & 85.7 & 7.3 & 0.2 & 6.8 & 99.1 & 0.2 & 0.0 & 0.6 \\
\hline Europe & 35.1 & 13.0 & 4.5 & 47.3 & 89.3 & 0.9 & 2.8 & 7.1 \\
\hline South Asia & 73.9 & 21.6 & 0.8 & 3.7 & 97.8 & 1.0 & 0.2 & 1.0 \\
\hline East Asia & 72.0 & 26.8 & 0.2 & 1.0 & 98.8 & 0.9 & 0.0 & 0.2 \\
\hline Middle East/Africa & 80.6 & 9.3 & 0.0 & 10.1 & 97.3 & 0.1 & 0.0 & 2.6 \\
\hline Oceania & 89.8 & 10.2 & 0.0 & 0.0 & 99.9 & 0.1 & 0.0 & 0.0 \\
\hline WORLD & 50.2 & 18.4 & 3.5 & 27.8 & 95.0 & 1.1 & 0.8 & 3.1 \\
\hline
\end{tabular}


Table 3: Emissions per Tonnes-Km of Transport Services, by Mode

\begin{tabular}{|c|c|c|c|}
\hline \multicolumn{4}{|c|}{ Panel (A) Maritime Mode } \\
\hline Ship Type & $\begin{array}{l}\text { C02 per } \\
\text { tonnes- } \\
\text { km }\end{array}$ & GTAP Sectors & Source \\
\hline Bulk & 4.5 & $\begin{array}{l}\text { Bulk agriculture, forestry, minerals, } \\
\text { coal products }\end{array}$ & University of Athens, 2008 \\
\hline Container & 12.1 & $\begin{array}{l}\text { Processed agriculture, fishing, textiles, } \\
\text { wearing apparel, leather products, } \\
\text { wood products, paper products and } \\
\text { publishing, ferrous metals, metals nec, } \\
\text { metal products, motor vehicles and } \\
\text { parts, transport equipment nec, } \\
\text { electronic equipment, machinery and } \\
\text { equipment, manufactures nec }\end{array}$ & University of Athens, 2008 \\
\hline Oil Tanker & 5 & Oil & University of Athens, 2008 \\
\hline LNG & 16.3 & Gas & University of Athens, 2008 \\
\hline LPG & 12.7 & Petroleum & University of Athens, 2008 \\
\hline Chemical & 10.1 & Chemical products & University of Athens, 2008 \\
\hline \multicolumn{4}{|c|}{$\begin{array}{l}\text { Panel (B) Land Mode } \\
\end{array}$} \\
\hline $\begin{array}{l}\text { Mode } \\
\text { Type }\end{array}$ & $\begin{array}{l}\text { C02 per } \\
\text { tonnes- } \\
\text { km }\end{array}$ & & Source \\
\hline $\begin{array}{l}\text { Road } \\
\text { Rail }\end{array}$ & $\begin{array}{c}119.7 \\
22.7\end{array}$ & & $\begin{array}{l}\text { Giannouli and Mellios, EEA, } \\
2005\end{array}$ \\
\hline \multicolumn{4}{|c|}{ Panel (C) Air Mode } \\
\hline $\begin{array}{l}\text { Plane } \\
\text { Type }\end{array}$ & $\begin{array}{l}\text { C02 per } \\
\text { tonnes- } \\
\text { km }\end{array}$ & & Source \\
\hline $\begin{array}{l}\text { Boeing } \\
747\end{array}$ & 552 & & Maersk Line, 2007 \\
\hline Various & $476-1020$ & & $\begin{array}{l}\text { California Climate Change } \\
2006\end{array}$ \\
\hline $\begin{array}{l}\text { US Cargo } \\
\text { Fleet }\end{array}$ & 963.45 & & $\begin{array}{l}\text { Authors' calculations based on } \\
\text { ATA fuel usage data }\end{array}$ \\
\hline $\begin{array}{l}\text { US Cargo } \\
\text { Fleet }\end{array}$ & 912 & & $\begin{array}{l}\text { Authors' calculations based on } \\
\text { Aircraft Economics } 1999 \text { data }\end{array}$ \\
\hline
\end{tabular}


Table 4. Output and Transport Emission Shares and Intensities, by Region

\begin{tabular}{|c|c|c|c|c|c|c|c|c|c|c|c|}
\hline & \multirow{2}{*}{\multicolumn{3}{|c|}{ Emission Shares (\% of World) }} & \multicolumn{8}{|c|}{ Emission Intensities (CO2 $\mathrm{g} / \$)$} \\
\hline & & & & \multicolumn{4}{|c|}{ Exports } & \multicolumn{4}{|c|}{ Imports } \\
\hline & \multicolumn{2}{|c|}{ Transport } & \multirow[t]{2}{*}{ Output } & \multirow[t]{2}{*}{ Total } & \multirow[t]{2}{*}{ Output* } & \multicolumn{2}{|c|}{ Transport } & \multirow[t]{2}{*}{ Total } & \multirow[t]{2}{*}{ Output* } & \multicolumn{2}{|c|}{ Transport } \\
\hline & Importer & Exporter & & & & Grams & Share \% & & & Grams & Share \% \\
\hline North America & 20.1 & 35.2 & 15.9 & 606 & 270 & 336 & $55 \%$ & 395 & 259 & 136 & $34 \%$ \\
\hline Central America & 0.9 & 0.7 & 0.8 & 557 & 404 & 153 & $27 \%$ & 510 & 376 & 135 & $26 \%$ \\
\hline South America & 3.8 & 6.9 & 9.4 & 1476 & 1138 & 337 & $23 \%$ & 760 & 474 & 286 & $38 \%$ \\
\hline Europe & 31.1 & 25.4 & 19.4 & 262 & 179 & 83 & $32 \%$ & 355 & 253 & 101 & $29 \%$ \\
\hline South Asia & 2.0 & 0.9 & 7.0 & 674 & 581 & 93 & $14 \%$ & 731 & 562 & 169 & $23 \%$ \\
\hline $\begin{array}{l}\text { East Asia } \\
\text { Middle }\end{array}$ & 31.4 & 15.0 & 31.1 & 306 & 224 & 81 & $26 \%$ & 562 & 352 & 210 & $37 \%$ \\
\hline East/Africa & 8.6 & 13.1 & 14.5 & 1176 & 908 & 268 & $23 \%$ & 697 & 476 & 221 & $32 \%$ \\
\hline Oceania & 2.0 & 2.8 & 1.9 & 1008 & 701 & 307 & $30 \%$ & 440 & 245 & 194 & $44 \%$ \\
\hline WORLD & 100 & 100 & 100 & 445 & 300 & 146 & $33 \%$ & 445 & 300 & 145 & $33 \%$ \\
\hline \multicolumn{12}{|c|}{ Selected Countries } \\
\hline United States & 10.7 & 32.5 & 12.0 & 739 & 251 & 488 & $66 \%$ & 366 & 271 & 94 & $26 \%$ \\
\hline China & 6.7 & 3.5 & 20.8 & 426 & 363 & 63 & $15 \%$ & 430 & 293 & 138 & $32 \%$ \\
\hline India & 1.5 & 0.6 & 4.9 & 707 & 612 & 95 & $13 \%$ & 698 & 516 & 182 & $26 \%$ \\
\hline
\end{tabular}

Note. Total emissions per dollar are calculated as the sum of transport and output emission intensities. *For comparability with transport emissions, output emissions are constructed as a weighted average of sector level output emissions, using trade rather than output weights. 
Table 5: Likelihood of CO2 Reductions through International Trade

\begin{tabular}{|c|c|c|c|}
\hline By Importer & $\begin{array}{c}\text { Fraction } \\
(\%)\end{array}$ & By Sector & $\begin{array}{l}\text { Fraction } \\
(\%)\end{array}$ \\
\hline Singapore & 6.2 & Leather products & 12.7 \\
\hline Japan & 7.0 & Wood products & 12.8 \\
\hline Sweden & 9.0 & Wearing apparel & 15.8 \\
\hline Denmark & 10.1 & Motor vehicles and parts & 16.6 \\
\hline France & 10.8 & Forestry & 17.8 \\
\hline Germany & 11.0 & Textiles & 20.3 \\
\hline Portugal & 12.5 & Petroleum, coal products & 21.1 \\
\hline Austria & 12.6 & Metal products & 22.4 \\
\hline Italy & 13.9 & Paper products, publishing & 24.1 \\
\hline Rest of European Countries & 14.6 & Machinery and equipment nec & 24.9 \\
\hline United Kingdom & 15.3 & Transport equipment nec & 26.8 \\
\hline Finland & 17.0 & Minerals & 27.0 \\
\hline Oceania countries & 17.0 & Manufactures nec & 29.8 \\
\hline Belgium & 18.3 & Fishing & 30.3 \\
\hline Korea & 18.8 & Oil & 33.6 \\
\hline Netherlands & 19.1 & Ferrous metals & 36.3 \\
\hline Mexico & 19.6 & Mineral products nec & 37.2 \\
\hline Spain & 21.2 & Gas & 37.4 \\
\hline Ireland & 21.7 & Electronic equipment & 39.2 \\
\hline Taiwan & 22.5 & Metals nec & 40.1 \\
\hline Greece & 24.1 & Chemical, rubber, plastic products & 40.7 \\
\hline Brazil & 24.7 & Bulk Agriculture & 41.6 \\
\hline $\begin{array}{l}\text { United States } \\
\text { Central and Caribbean }\end{array}$ & 25.1 & Processed Agriculture & 42.7 \\
\hline Americas & 26.1 & & \\
\hline European Union & 29.3 & & \\
\hline Canada & 30.0 & & \\
\hline South Africa & 31.0 & & \\
\hline India & 35.9 & & \\
\hline Rest of South East Asia & 37.6 & & \\
\hline Sub Saharan Africa & 40.5 & & \\
\hline Malaysia and Indonesia & 43.7 & & \\
\hline South and Other Americas & 43.9 & & \\
\hline Argentina & 45.2 & & \\
\hline Chile & 46.6 & & \\
\hline Russia & 49.6 & & \\
\hline Rest of South Asia & 51.3 & & \\
\hline $\begin{array}{l}\text { China and Hong Kong } \\
\text { Middle Eastern and North }\end{array}$ & 52.8 & & \\
\hline Africa & 64.6 & & \\
\hline Other East Europe & 64.7 & & \\
\hline Rest of East Asia & 67.3 & & \\
\hline Average & 26.5 & Average & 26.5 \\
\hline
\end{tabular}


Table 6. Worldwide Changes in Output, Trade and Associated Emissions by Scenario

\begin{tabular}{|c|c|c|c|c|c|c|}
\hline & \multirow[b]{2}{*}{ Doha S04 } & \multirow[b]{2}{*}{ Doha S05 } & \multirow[b]{2}{*}{ Doha S09 } & \multirow{2}{*}{$\begin{array}{r}\text { Full } \\
\text { Liberalization } \\
\end{array}$} & \multicolumn{2}{|c|}{ GDP growth 2004-2020 } \\
\hline & & & & & Per Annum & Cummulative \\
\hline \multicolumn{7}{|l|}{$\%$ Change } \\
\hline Output & -0.09 & -0.04 & -0.22 & -1.22 & 3.57 & 75.2 \\
\hline \multicolumn{7}{|l|}{ Exports: } \\
\hline Value & 0.07 & -0.13 & 1.12 & 6.09 & 3.76 & 80.4 \\
\hline Weight & 0.24 & -0.08 & 0.57 & 5.72 & 5.83 & 147.8 \\
\hline $\mathrm{Kg}-\mathrm{Km}$ & 0.46 & -0.06 & 1.10 & 6.05 & 6.48 & 173.3 \\
\hline \multicolumn{7}{|l|}{ Modal Use (value) } \\
\hline Sea & 0.54 & 0.03 & 2.70 & 12.25 & 4.52 & 102.8 \\
\hline Air & -0.31 & -0.34 & 1.78 & 7.41 & 3.82 & 82.1 \\
\hline Rail & -0.23 & -0.23 & -1.20 & -3.72 & 2.88 & 57.6 \\
\hline Road & -0.50 & -0.27 & -1.85 & -4.66 & 2.21 & 41.8 \\
\hline \multicolumn{7}{|l|}{ Modal Use (KG-KM) } \\
\hline Sea & 0.51 & -0.04 & 1.16 & 6.32 & 6.59 & 177.5 \\
\hline Air & -0.48 & -0.44 & 3.60 & 13.14 & 4.93 & 116.1 \\
\hline Rail & -0.33 & -0.60 & -0.63 & 5.21 & 4.82 & 112.5 \\
\hline Road & -0.52 & -0.27 & -1.33 & -4.73 & 3.69 & 78.7 \\
\hline \multicolumn{7}{|l|}{$\begin{array}{l}\text { C02 Emissions } \\
\text { (\% change) }\end{array}$} \\
\hline Output & 0.84 & 0.42 & 0.92 & 0.41 & 4.50 & 102.2 \\
\hline \multicolumn{7}{|l|}{ Transport: } \\
\hline HIGH Scenario & -0.06 & -0.22 & 2.10 & 8.63 & 5.10 & 121.7 \\
\hline LOW Scenario & 0.04 & -0.16 & 1.72 & 7.51 & 5.14 & 123.1 \\
\hline
\end{tabular}


Table 7. Trade value and output growth by emission intensity: WLS estimates

\begin{tabular}{|c|c|c|c|c|}
\hline \multirow[t]{2}{*}{$\begin{array}{l}\text { Dependent } \\
\text { Variable: }\end{array}$} & \multicolumn{2}{|c|}{ Trade Growth } & \multicolumn{2}{|c|}{ Output Growth } \\
\hline & $\begin{array}{c}\text { Full } \\
\text { Liberalizatic }\end{array}$ & GDP growth & $\begin{array}{c}\text { Full } \\
\text { Liberalizatio }\end{array}$ & GDP growth \\
\hline \multicolumn{3}{|c|}{ Panel (A) On quartiles of transport emission intensity } & \multicolumn{2}{|c|}{ On quartiles of output emission intensity } \\
\hline II quartile & $\begin{array}{c}0.036^{* * *} \\
{[0.013]}\end{array}$ & $\begin{array}{c}0.093^{* * *} \\
{[0.025]}\end{array}$ & $\begin{array}{l}-0.016 \\
{[0.015]}\end{array}$ & $\begin{array}{c}0.085 \\
{[0.062]}\end{array}$ \\
\hline III quartile & $\begin{array}{c}0.040^{* * *} \\
{[0.012]}\end{array}$ & $\begin{array}{c}0.229^{* * *} \\
{[0.029]}\end{array}$ & $\begin{array}{c}0.006 \\
{[0.009]}\end{array}$ & $\begin{array}{l}0.094^{* *} \\
{[0.043]}\end{array}$ \\
\hline IV quartile & $\begin{array}{c}0.049^{* * *} \\
{[0.012]}\end{array}$ & $\begin{array}{c}0.417^{* * *} \\
{[0.032]}\end{array}$ & $\begin{array}{c}0.010 \\
{[0.012]}\end{array}$ & $\begin{array}{c}0.314^{* * *} \\
{[0.049]}\end{array}$ \\
\hline Constant & $\begin{array}{c}-0.001 \\
{[0.006]} \\
\end{array}$ & $\begin{array}{c}0.361^{* * *} \\
{[0.015]}\end{array}$ & $\begin{array}{c}-0.015^{* * *} \\
{[0.006]}\end{array}$ & $\begin{array}{c}0.403^{* * *} \\
{[0.028]}\end{array}$ \\
\hline $\begin{array}{l}\mathrm{N} \\
\mathrm{R} 2 \\
\end{array}$ & $\begin{array}{c}34,162 \\
0.007\end{array}$ & $\begin{array}{c}34,162 \\
0.570 \\
\end{array}$ & $\begin{array}{c}879 \\
0.012 \\
\end{array}$ & $\begin{array}{c}879 \\
0.195 \\
\end{array}$ \\
\hline \multicolumn{5}{|c|}{ Panel (B) On transport emission intensity determinants } \\
\hline Distance & $\begin{array}{c}0.035^{* * *} \\
{[0.005]}\end{array}$ & $\begin{array}{c}0.055^{* * *} \\
{[0.009]}\end{array}$ & & \\
\hline Weight/Value & $\begin{array}{c}0.019^{* * *} \\
{[0.004]}\end{array}$ & $\begin{array}{c}0.090^{* * *} \\
{[0.008]}\end{array}$ & & \\
\hline air use & $\begin{array}{c}0.010^{* * *} \\
{[0.002]}\end{array}$ & $\begin{array}{c}0.008^{* *} \\
{[0.004]}\end{array}$ & & \\
\hline Constant & $\begin{array}{c}-0.182^{* * *} \\
{[0.046]} \\
\end{array}$ & $\begin{array}{c}0.149^{*} \\
{[0.086]}\end{array}$ & & \\
\hline $\begin{array}{l}\mathrm{N} \\
\mathrm{R} 2 \\
\end{array}$ & $\begin{array}{c}30,906 \\
0.051\end{array}$ & $\begin{array}{c}30,906 \\
0.602 \\
\end{array}$ & & \\
\hline
\end{tabular}

Note. Robust standard errors in parentheses. ${ }^{* * *} \mathrm{P}<0.01,{ }^{* *} \mathrm{P}<0.05,{ }^{*} \mathrm{P}<0.1$. In panel $(\mathrm{A})$ quartiles are based on the distribution of (log) emission intensity. A trade flow's emission intensity is calculated using the LOW scenario emissions content. All coefficients are estimates by WLS using 2004 export values as weights. All regressions include unreported indicator variables for imports and exports involving South Africa. This is done in order to account for the fact that in the GTAP GDP growth simulation South Africa is used in closing the model. The Gas sector is a huge outlier and so it is removed from the sample. 
Appendix Table A1. Baseline Descriptives by Commodity

\begin{tabular}{lc|c|ccc}
\hline \hline Commodity & Tariff & Weight/Value & Share of: & & \\
\hline & & & World & Trade & Kg-Km \\
& & & Output & Value & \\
\hline Bulk Agriculture & 8.98 & 3.56 & 2.51 & 1.40 & 4.69 \\
Processed Agriculture & 9.68 & 1.24 & 16.39 & 6.69 & 5.54 \\
Forestry & 1.13 & 8.87 & 0.55 & 0.16 & 0.74 \\
Fishing & 3.37 & 0.35 & 0.51 & 0.17 & 0.03 \\
Minerals & 1.56 & 16.56 & 1.63 & 1.61 & 26.53 \\
Oil & 1.22 & 5.01 & 2.86 & 5.86 & 23.69 \\
Gas & 0.09 & 6.33 & 0.61 & 0.87 & 3.52 \\
Textiles & 6.91 & 0.38 & 2.88 & 3.20 & 0.72 \\
Wearing apparel & 7.69 & 0.07 & 2.14 & 2.36 & 0.12 \\
Leather products & 7.37 & 0.21 & 0.82 & 1.24 & 0.19 \\
Wood products & 1.66 & 1.21 & 2.35 & 2.04 & 1.21 \\
Paper products, publishing & 1.64 & 1.41 & 5.05 & 2.34 & 1.97 \\
Petroleum, coal products & 3.25 & 5.13 & 4.72 & 2.43 & 8.27 \\
Chemical, rubber, plastic products & 2.57 & 0.90 & 12.22 & 14.22 & 8.15 \\
Mineral products nec & 3.71 & 2.48 & 2.66 & 1.28 & 1.95 \\
Ferrous metals & 2.46 & 2.43 & 3.69 & 3.01 & 4.74 \\
Metals nec & 2.11 & 0.63 & 2.14 & 3.00 & 1.31 \\
Metal products & 3.03 & 0.90 & 4.20 & 2.33 & 1.21 \\
Motor vehicles and parts & 3.45 & 0.19 & 7.82 & 10.48 & 0.98 \\
Transport equipment nec & 2.01 & 0.11 & 2.18 & 3.10 & 0.26 \\
Electronic equipment & 1.14 & 0.08 & 7.78 & 13.36 & 1.01 \\
Machinery and equipment nec & 2.58 & 0.23 & 11.66 & 16.66 & 2.88 \\
Manufactures nec & 2.57 & 0.19 & 2.64 & 2.20 & 0.31 \\
\hline TOTAL & 3.21 & 1.31 & 100 & 100 & 100 \\
\hline \hline
\end{tabular}


Appendix Table A2. Sectoral Modal Shares, by trade value and KG-KM

\begin{tabular}{|c|c|c|c|c|c|c|c|c|}
\hline \multirow[t]{2}{*}{ Commodity } & \multicolumn{4}{|c|}{ By Value } & \multicolumn{4}{|c|}{ By KG-KM } \\
\hline & Sea & Air & Rail & Road & Sea & Air & Rail & Road \\
\hline Bulk Agriculture & 76.95 & 3.18 & 2.87 & 16.95 & 97.02 & 0.35 & 1.28 & 1.36 \\
\hline Processed Agriculture & 56.42 & 2.77 & 1.98 & 38.68 & 91.77 & 0.54 & 0.84 & 6.86 \\
\hline Forestry & 67.76 & 2.41 & 7.88 & 21.83 & 92.21 & 0.52 & 3.60 & 3.67 \\
\hline Fishing & 41.73 & 25.78 & 0.40 & 32.05 & 71.02 & 19.51 & 0.11 & 9.36 \\
\hline Minerals & 71.70 & 20.38 & 2.82 & 5.07 & 98.48 & 0.08 & 0.65 & 0.79 \\
\hline Oil & 96.45 & 0.00 & 1.16 & 2.39 & 98.41 & 0.00 & 0.31 & 1.28 \\
\hline Gas & 62.12 & 0.00 & 13.37 & 24.50 & 96.00 & 0.00 & 1.10 & 2.90 \\
\hline Textiles & 58.19 & 9.08 & 0.61 & 32.07 & 80.96 & 4.82 & 0.13 & 14.08 \\
\hline Wearing apparel & 52.56 & 17.93 & 0.58 & 28.88 & 76.03 & 16.23 & 0.11 & 7.63 \\
\hline Leather products & 56.85 & 14.43 & 0.31 & 28.37 & 81.85 & 8.68 & 0.12 & 9.35 \\
\hline Wood products & 50.86 & 2.05 & 8.75 & 38.25 & 87.74 & 0.47 & 2.71 & 9.08 \\
\hline Paper products, publishing & 47.01 & 5.00 & 5.80 & 42.11 & 89.92 & 0.95 & 1.57 & 7.56 \\
\hline Petroleum, coal products & 89.07 & 0.24 & 2.97 & 7.37 & 97.43 & 0.12 & 0.68 & 1.77 \\
\hline Chemical, rubber, plastic products & 45.96 & 16.44 & 2.42 & 35.08 & 91.35 & 1.11 & 1.11 & 6.44 \\
\hline Mineral products nec & 49.27 & 7.94 & 2.25 & 40.41 & 90.66 & 0.65 & 1.26 & 7.43 \\
\hline Ferrous metals & 65.15 & 1.36 & 7.08 & 26.14 & 94.36 & 0.17 & 1.66 & 3.81 \\
\hline Metals nec & 57.56 & 13.23 & 3.09 & 26.03 & 93.93 & 0.89 & 0.73 & 4.45 \\
\hline Metal products & 43.65 & 10.16 & 2.08 & 44.03 & 77.43 & 7.32 & 0.41 & 14.85 \\
\hline Motor vehicles and parts & 44.81 & 3.42 & 12.95 & 38.66 & 81.58 & 4.34 & 2.53 & 11.54 \\
\hline Transport equipment nec & 34.04 & 43.52 & 3.35 & 19.03 & 86.02 & 9.86 & 0.92 & 3.20 \\
\hline Electronic equipment & 32.78 & 50.21 & 0.58 & 16.38 & 68.19 & 28.61 & 0.07 & 3.13 \\
\hline Machinery and equipment nec & 41.79 & 25.34 & 2.31 & 30.52 & 81.66 & 11.42 & 0.35 & 6.57 \\
\hline Manufactures nec & 36.45 & 42.82 & 0.61 & 20.07 & 86.76 & 8.95 & 0.16 & 4.13 \\
\hline TOTAL & 50.25 & 18.36 & 3.50 & 27.81 & 95.05 & 1.10 & 0.78 & 3.06 \\
\hline
\end{tabular}


Appendix Table A3. Output and Transport Emission Shares and Intensities, by Country

\begin{tabular}{|c|c|c|c|c|c|c|c|c|c|c|c|}
\hline & \multicolumn{3}{|c|}{$\begin{array}{l}\text { Emission Shares } \\
\text { (\% of World) }\end{array}$} & \multicolumn{4}{|c|}{$\begin{array}{l}\text { Emission Intensities (CO2 g/\$) } \\
\text { By Exporter }\end{array}$} & \multicolumn{4}{|c|}{$\begin{array}{l}\text { Emission Intensities }(\mathrm{CO} 2 \mathrm{~g} / \$) \\
\text { By Importer }\end{array}$} \\
\hline & \multicolumn{2}{|c|}{ Transport } & \multirow[t]{2}{*}{ Output } & \multirow[t]{2}{*}{ Total } & \multirow[t]{2}{*}{ Output* } & \multicolumn{2}{|c|}{ Transport } & \multirow[t]{2}{*}{ Total } & \multirow[t]{2}{*}{ Output* } & \multicolumn{2}{|c|}{ Transport } \\
\hline & Importer & Exporter & & & & Grams & Share & & & Grams & Share \\
\hline Argentina & 0.56 & 1.20 & 1.47 & 2351 & 1924 & 427 & 18.2 & 621 & 282 & 339 & 54.6 \\
\hline Austria & 0.71 & 0.62 & 0.18 & 160 & 82 & 79 & 49.1 & 227 & 142 & 85 & 37.6 \\
\hline Belgium & 1.41 & 1.45 & 0.31 & 176 & 103 & 73 & 41.4 & 292 & 230 & 63 & 21.4 \\
\hline Brazil & 1.40 & 3.17 & 4.53 & 1477 & 1103 & 374 & 25.3 & 766 & 487 & 279 & 36.4 \\
\hline Canada & 3.52 & 1.54 & 2.08 & 429 & 363 & 66 & 15.4 & 368 & 205 & 163 & 44.4 \\
\hline China and Hong Kong & 6.73 & 3.45 & 20.85 & 426 & 363 & 63 & 14.8 & 430 & 293 & 138 & 32.0 \\
\hline Chile & 0.79 & 0.64 & 0.29 & 639 & 391 & 247 & 38.7 & 945 & 503 & 442 & 46.8 \\
\hline $\begin{array}{l}\text { Central and Caribbean } \\
\text { Americas }\end{array}$ & 0.92 & 0.70 & 0.85 & 557 & 404 & 153 & 27.5 & 510 & 376 & 135 & 26.4 \\
\hline Denmark & 0.59 & 1.02 & 0.16 & 309 & 123 & 186 & 60.1 & 313 & 193 & 119 & 38.2 \\
\hline European Union & 2.30 & 2.10 & 1.91 & 264 & 169 & 95 & 36.0 & 333 & 242 & 91 & 27.4 \\
\hline Rest of East Asia & 0.08 & 0.26 & 0.76 & 2183 & 1679 & 505 & 23.1 & 700 & 546 & 154 & 22.0 \\
\hline Finland & 0.45 & 0.24 & 0.17 & 152 & 103 & 49 & 32.2 & 352 & 248 & 104 & 29.5 \\
\hline France & 2.82 & 2.39 & 1.56 & 185 & 112 & 73 & 39.4 & 291 & 209 & 82 & 28.3 \\
\hline Germany & 5.82 & 3.61 & 1.62 & 115 & 61 & 54 & 46.9 & 327 & 217 & 109 & 33.5 \\
\hline Greece & 0.48 & 0.36 & 0.23 & 497 & 253 & 244 & 49.1 & 370 & 260 & 110 & 29.8 \\
\hline India & 1.54 & 0.64 & 4.90 & 707 & 612 & 95 & 13.4 & 698 & 516 & 182 & 26.1 \\
\hline Ireland & 0.54 & 0.17 & 0.20 & 104 & 86 & 18 & 17.5 & 252 & 153 & 99 & 39.3 \\
\hline Italy & 2.85 & 1.89 & 1.13 & 155 & 84 & 71 & 46.0 & 391 & 285 & 105 & 27.0 \\
\hline Japan & 10.40 & 1.97 & 2.35 & 105 & 63 & 42 & 40.3 & 761 & 457 & 305 & 40.0 \\
\hline Korea & 4.11 & 2.94 & 0.90 & 244 & 108 & 136 & 55.6 & 650 & 410 & 240 & 37.0 \\
\hline $\begin{array}{l}\text { Middle Eastern and North } \\
\text { Africa }\end{array}$ & 4.27 & 9.24 & 7.37 & 1068 & 808 & 259 & 24.3 & 606 & 449 & 156 & 25.8 \\
\hline
\end{tabular}


Appendix Table A3. (cont'd) Output and Transport Emission Shares and Intensities, by Country

\begin{tabular}{|c|c|c|c|c|c|c|c|c|c|c|c|}
\hline & \multicolumn{3}{|c|}{$\begin{array}{l}\text { Emission Shares } \\
\text { (\% of World) }\end{array}$} & \multicolumn{4}{|c|}{$\begin{array}{l}\text { Emission Intensities }(\mathrm{CO} 2 \mathrm{~g} / \$) \\
\text { By Exporter }\end{array}$} & \multicolumn{4}{|c|}{$\begin{array}{l}\text { Emission Intensities }(\mathrm{CO} 2 \mathrm{~g} / \$) \\
\text { By Importer }\end{array}$} \\
\hline & \multicolumn{2}{|c|}{ Transport } & \multirow[t]{2}{*}{ Output } & \multirow[t]{2}{*}{ Total } & \multirow[t]{2}{*}{ Output* } & \multicolumn{2}{|c|}{ Transport } & \multirow[t]{2}{*}{ Total } & \multirow[t]{2}{*}{ Output* } & \multicolumn{2}{|c|}{ Transport } \\
\hline & Importer & Exporter & & & & Grams & Share & & & Grams & Share \\
\hline Mexico & 5.92 & 1.13 & 1.78 & 288 & 211 & 76 & 26.6 & 674 & 245 & 429 & 63.6 \\
\hline Malaysia and Indonesia & 2.48 & 3.90 & 2.52 & 545 & 333 & 212 & 38.9 & 522 & 319 & 203 & 38.8 \\
\hline Netherlands & 1.41 & 1.70 & 0.69 & 348 & 226 & 122 & 35.0 & 456 & 348 & 108 & 23.6 \\
\hline Oceania countries & 2.02 & 2.77 & 1.87 & 1008 & 701 & 307 & 30.4 & 440 & 245 & 194 & 44.2 \\
\hline Other East Europe & 2.15 & 2.73 & 4.34 & 1156 & 949 & 207 & 17.9 & 626 & 497 & 130 & 20.7 \\
\hline Rest of European Countries & 1.34 & 0.93 & 0.49 & 213 & 158 & 55 & 25.8 & 281 & 181 & 99 & 35.4 \\
\hline Portugal & 0.40 & 0.26 & 0.15 & 172 & 88 & 83 & 48.6 & 354 & 266 & 87 & 24.7 \\
\hline Rest of South East Asia & 2.16 & 1.33 & 3.12 & 525 & 442 & 84 & 15.9 & 503 & 348 & 155 & 30.8 \\
\hline Rest of South Asia & 0.50 & 0.22 & 2.10 & 583 & 496 & 88 & 15.0 & 808 & 670 & 138 & 17.1 \\
\hline Russia & 0.90 & 1.91 & 3.93 & 1177 & 1014 & 163 & 13.8 & 570 & 451 & 119 & 20.9 \\
\hline Singapore & 2.40 & 0.49 & 0.03 & 78 & 28 & 50 & 63.9 & 492 & 259 & 233 & 47.3 \\
\hline South Africa & 2.42 & 1.62 & 1.03 & 985 & 618 & 367 & 37.2 & 1019 & 403 & 616 & 60.4 \\
\hline Spain & 2.02 & 1.41 & 0.97 & 231 & 133 & 98 & 42.3 & 391 & 290 & 102 & 26.0 \\
\hline Sweden & 1.17 & 1.17 & 0.17 & 173 & 51 & 122 & 70.6 & 315 & 160 & 155 & 49.2 \\
\hline Sub Saharan Africa & 1.92 & 2.27 & 6.14 & 1699 & 1447 & 252 & 14.8 & 856 & 608 & 248 & 29.0 \\
\hline South and Other Americas & 1.00 & 1.93 & 3.08 & 1430 & 1142 & 288 & 20.2 & 732 & 518 & 215 & 29.3 \\
\hline Taiwan & 3.09 & 0.70 & 0.57 & 158 & 117 & 41 & 26.0 & 564 & 324 & 240 & 42.6 \\
\hline United Kingdom & 3.78 & 1.38 & 1.16 & 169 & 112 & 57 & 33.6 & 341 & 234 & 106 & 31.2 \\
\hline United States & 10.65 & 32.53 & 12.03 & 739 & 251 & 488 & 66.0 & 366 & 271 & 94 & 25.8 \\
\hline TOTAL & 100.00 & 100.00 & 100.00 & 445 & 300 & 146 & 32.70 & 445 & 300 & 146 & 32.70 \\
\hline
\end{tabular}

Note. Total emissions per dollar are calculated as the sum of transport and output emission intensities. *For comparability with transport

emissions, output emissions are constructed as a weighted average of sector level output emissions, using trade rather than output weights. 
Appendix Table A4. Projected GDP Growth

\begin{tabular}{|c|c|c|c|c|c|}
\hline \multirow[b]{2}{*}{ Country/Region } & \multirow{2}{*}{$\begin{array}{l}\text { GDP in } 2004 \\
\text { (billion } \\
\text { USD) }\end{array}$} & \multicolumn{4}{|c|}{ Projected Growth, 2004-2020, \% } \\
\hline & & GDP & Capital & Unskilled Labor & Skilled Labor \\
\hline Argentina & 150 & 73.3 & 48.3 & 24.5 & 146.2 \\
\hline Austria & 292 & 47.6 & 51.0 & 15.1 & 3.2 \\
\hline Belgium & 384 & 41.8 & 58.0 & 2.6 & -8.0 \\
\hline Brazil & 617 & 76.4 & 68.0 & 13.1 & 61.9 \\
\hline Canada & 979 & 51.1 & 68.1 & 28.4 & 15.5 \\
\hline Central America and Caribbean & 287 & 69.9 & 85.8 & 33.5 & 76.4 \\
\hline Chile & 90 & 96.5 & 128.2 & 51.6 & 132.9 \\
\hline China and Hong Kong & 1,837 & 174.2 & 266.0 & 14.1 & 87.1 \\
\hline Denmark & 244 & 41.0 & 58.1 & 7.8 & -3.3 \\
\hline East Asia & 26 & 63.6 & 68.3 & 25.4 & 35.9 \\
\hline Rest of European Union & 680 & 73.6 & 73.2 & -14.9 & -7.8 \\
\hline Finland & 186 & 60.2 & 50.5 & 8.7 & -2.6 \\
\hline France & 2,046 & 44.1 & 52.5 & 16.9 & 4.8 \\
\hline Germany & 2,741 & 33.3 & 36.1 & 8.0 & -3.2 \\
\hline Greece & 205 & 47.3 & 72.8 & 15.1 & 3.2 \\
\hline India & 641 & 139.1 & 161.5 & 28.3 & 88.8 \\
\hline Ireland & 182 & 102.3 & 135.6 & 46.6 & 31.4 \\
\hline Italy & 1,678 & 41.6 & 42.6 & -0.7 & -10.9 \\
\hline Japan & 4,659 & 30.6 & 49.3 & 2.9 & -10.5 \\
\hline Korea & 676 & 109.0 & 118.6 & 35.8 & 147.7 \\
\hline Malaysia and Indonesia & 370 & 130.5 & 127.5 & 47.2 & 174.4 \\
\hline Mexico & 683 & 81.5 & 69.5 & 51.5 & 106.7 \\
\hline Middle Eastern and North Africa & 1,116 & 89.0 & 92.4 & 34.4 & 62.5 \\
\hline Netherlands & 579 & 51.5 & 52.8 & 16.6 & 4.6 \\
\hline Oceania countries & 756 & 72.5 & 83.8 & 31.5 & 13.2 \\
\hline Other East Europe & 553 & 89.2 & 82.3 & 12.9 & 41.7 \\
\hline Portugal & 168 & 47.2 & 77.8 & 9.4 & -1.9 \\
\hline Rest of European Countries & 623 & 39.9 & 35.9 & 21.7 & 9.1 \\
\hline Rest of South Asia & 185 & 120.1 & 122.8 & 40.4 & 79.8 \\
\hline Rest of South East Asia & 310 & 92.7 & 88.2 & 21.0 & 76.1 \\
\hline Russia & 570 & 67.6 & 73.2 & -1.6 & 6.6 \\
\hline Singapore & 107 & 116.5 & 131.4 & 10.5 & 19.8 \\
\hline South Africa & 214 & 69.0 & 675.8 & 26.2 & 36.7 \\
\hline South and Other Americas & 339 & 62.9 & 59.9 & 21.8 & 81.0 \\
\hline Spain & 1,040 & 56.6 & 84.0 & 17.4 & 5.3 \\
\hline Sub Saharan Africa & 310 & 77.1 & 85.9 & 51.6 & 72.5 \\
\hline Sweden & 346 & 49.0 & 48.5 & 14.3 & 2.4 \\
\hline Taiwan & 305 & 89.1 & 118.5 & 1.2 & 9.7 \\
\hline United Kingdom & 2,124 & 41.9 & 48.9 & 17.5 & 5.3 \\
\hline United States & 11,673 & 66.8 & 86.8 & 26.9 & 14.1 \\
\hline WORLD & $\begin{array}{l}40,970 \\
\end{array}$ & 64.6 & 83.3 & 18.7 & 21.8 \\
\hline
\end{tabular}

